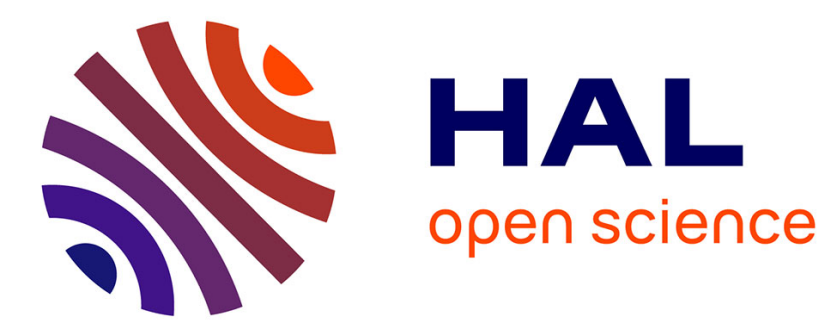

\title{
Arithmetic and Memorial Practices by and around Sophie Germain in the 19th Century
}

Jenny Boucard

\section{To cite this version:}

Jenny Boucard. Arithmetic and Memorial Practices by and around Sophie Germain in the 19th Century. Eva Kaufholz-Soldat \& Nicola Oswald. Against All Odds.Women's Ways to Mathematical Research Since 1800, Springer-Verlag, pp.185-230, 2020. halshs-03195261

\section{HAL Id: halshs-03195261 https://shs.hal.science/halshs-03195261}

Submitted on 10 Apr 2021

HAL is a multi-disciplinary open access archive for the deposit and dissemination of scientific research documents, whether they are published or not. The documents may come from teaching and research institutions in France or abroad, or from public or private research centers.
L'archive ouverte pluridisciplinaire HAL, est destinée au dépôt et à la diffusion de documents scientifiques de niveau recherche, publiés ou non, émanant des établissements d'enseignement et de recherche français ou étrangers, des laboratoires publics ou privés. 


\title{
Arithmetic and Memorial Practices by and around Sophie Germain in the 19th Century
}

\author{
Jenny Boucard*
}

Published in 2020 : Boucard Jenny (2020), "Arithmetic and Memorial Practices by and around Sophie Germain in the 19th Century", in Eva Kaufholz-Soldat Eva \& Nicola Oswald (eds), Against All Odds. Women in Mathematics (Europe, 19th and 20th Centuries), Springer Verlag.

Preprint Version (2019)

\begin{abstract}
Résumé
Sophie Germain (1776-1831) is an emblematic example of a woman who produced mathematics in the first third of the nineteenth century. Self-tanght, she was recognised for her work in the theory of elasticity and number theory. After some biographical elements, I will focus on her contribution to number theory in the context of the mathematical practices and social positions of the mathematicians of her time. I will then analyse some receptions and uses of Germain's life and scientific work under the French Third Republic.
\end{abstract}

\section{INTRODUCTION}

Biographical studies of women scientists considered as pioneers are an important part of the historical writings dedicated to the question of "women in mathematics": in particular, they highlight the range of the necessary adaptations, attitudes and reactions of the various actors involved in a given place and time in order to join traditionally male scholarly spheres. ${ }^{1}$ More generally, work on the relationship between women and science is part of questions developed since the 1970s about the production of science from a social and cultural perspective: they take into account scientific practices and discourses on science, non-institutionalised scholarly networks, and the circulation of knowledge or memorial practices.

In this paper, I chose to focus on a particular woman in mathematics: Sophie Germain (17761831). In history of mathematics, Germain is known for her work in elasticity theory and number theory. Many features of her life also contributed to her becoming a pioneer as a woman who produced

\footnotetext{
* Centre François Viète d'épistémologie et d'histoire des sciences et des techniques, Université de Nantes, jenny.boucard@univ-nantes.fr

1 See for example (Gardey, 2000; Renate et al., 2001) and Introduction.
} 
mathematics. ${ }^{2}$ Note for example that she became the first woman to be invited to the sessions of the Paris Académie des sciences as a mathematician (and not as a wife). ${ }^{3}$

Germain's life and work have already been the subject of many academic studies. In this chapter, after recalling some biographical elements of Germain, I first discuss how Germain was able or not to infiltrate scholarly networks and collaborate with other mathematicians to research in number theory. For this purpose I rely on A. Del Centina, R. Laubenbacher and D. Pengelley's studies of Germain's published and unpublished number-theoretical writings, published or not (Del Centina, 2005; 2008; Del Centina and Fiocca, 2012; Laubenbacher and Pengelley, 1999; 2010). I situate Germain's work in the context of number theory practices ${ }^{4}$ and contemporary mechanisms of mathematical circulation, using a corpus of number theory texts based on a systematic study of mathematical journals from the first third of the nineteenth century (Boucard, 2011; 2015). I can thus question the specificities of her work from the point of view of her gender and the status of number theory in France at the time. Then I study how Germain's life and capability to do mathematics alone or in collaboration with male mathematicians was used in France in debates on the women question mainly from the 1870s to the 1910s. This period is particularly interesting for several reasons: new receptions of Germain's philosophical and mathematical works, the importance of scholarly commemorations under the Third Republic, the rise of feminist movements(Offen, 2012), reflections and reforms on secondary education and higher education (especially for women), the development of new social sciences and the growing importance of science in French society (let us recall the slogan of the Association pour l'avancement des sciences, created in 1872 : "For science, for the homeland" 5 .), and, more generally, debates on the place of women in science in general and mathematics in particular. Several of these references will illustrate different representations of women in mathematics through the construction of historical narratives around Germain.

\section{Biographical Elements of Germain: a Pioneer?}

Two texts published in the nineteenth century are usually used for the biography of Sophie Germain: Notice historique written by one of Germain's close friends, the mathematician Guglielmo Libri (1803-1869), who knew her well and to whom she related her childhood; and Étude sur la vie et les cenvres de Sophie Germain by the journalist Hippolyte Stupuy (1832-1900), published for the first time in 1879 when Stupuy's edition of Germain's philosophical work appeared. Much additional information can also be found in a recent work on Germain's work on the elastic theory of surfaces (Bucciarelli, 1980) and in books and articles about Germain's life (Boyé, 2017; Musielak, 2015). The aim of this section is to highlight the main events of her life present in most stories about Germain that contributed to the construction of Gemain's image as a pioneer in mathematics. Indeed, the stories existing about Germain's life particularly emphasise two aspects of her self-taught education that contribute to the

\footnotetext{
2 She appears systematically in the biographical collections of women mathematicians and is pre- sented as one of the first women to have done independent mathematical work. She is also one of the few women mathematicians, with Sophia Kovalevskaya (1850-1891), to have a stamp with her effigy (released March 18, 2016). More generally, she has also be included in books about great women in history: for example, she is one of the eighteen "exceptional women" according to Jean Haechler (Haechler, 2017). The historical reliability of some of these biographical collections is sometimes questionable, but it is interesting to note the place of Germain in them. She is also one of the only women to appear in current high school mathematics French textbooks, most often to define so-called Germain prime numbers.

3 The term "mathematician" was rarely used in the first half of the nineteenth century: it is the term "geometer"” that appeared most often in this period. Following the comment of one of the reviewers of this paper, I nevertheless chose this first term for the whole period studied here in order to avoid misunderstandings.

${ }^{4}$ By the study of mathematical practices I mean the description and analysis of the mathematical activities carried out by actors from the historical traces that are available to us. It is not the study of concepts or mathematical theories but that of an activity that articulates several elements (tools and mathematical objects, calculations, procedures, theorems, proofs, methods, etc.).

5 "Pour la science, pour la patrie"
} 
making of her exceptional status. First, passionate about mathematics from an early age, she had to face her family, who forbade her to study mathematics (she hid to study the books found in her father's library). Then, not allowed to participate in post-revolutionary institutions of higher education, she had to pretend to be a man to access to ressource of the École Polytechnique teaching and to communicate with teachers.

\section{II.1 A Self-Taught Mathematical Formation}

Sophie Germain was born in 1776 in a bourgeois family, "liberal and educated" (Stupuy, 1879, p. 3$)^{6}$ on rue Saint-Denis in Paris. Her father, Ambroise-François Germain (1726-1821), belonged to the corporation of clothiers and bonnetiers in Paris and was representative of the Tiers-État to the États généraux, then deputy to the Assemblée législative between 1790 and 1791 (the Constituants). ${ }^{7}$ He was known for his analysis of economic questions. He and his wife Marie-Madeleine Gruguelu (?-1823) had three daughters: Marie-Madeleine (1770-1804), Sophie and Angélique Ambroise (1779- ?). In 1790, the eldest married the notary Charles Lherbette (1752-1836), recent widower of Angélique Ambroisine Germain (1765-1787), cousin of Ambroise-François. They had two children, including Amand Jacques (1791-1864). Close to his two aunts, Amand Jacques was the witness of the second marriage of Angélique Ambroise and published a philosophical text written by Sophie after her death. In 1809, Angélique Ambroise first married René-Claude Geoffroy (1767-1831), a doctor from a family of pharmacists, then Henri Dutrochet (1776-1847), physician and botanist, elected to the Académie des sciences in 1828. Little additional information is known about the Germain family. It is nevertheless interesting to note that Germain's father may have established relationships withscholars during his political activities: for example, among the deputies of the États généraux for the generality of Paris were the astronomer Jean-Sylvain Bailly (1736-1793) and the doctor Joseph-Ignace Guillotin (1738-1814) (Tiers-État) and the mathematician Achille Pierre Dionis du Séjour (1734-1794) (Noblesse) (Lemay, 1991). Similarly, the two marriages of the youngest daughter suggest new links with families of doctors and naturalists.

Access to education for women was very limited under the Ancien Régime and was an issue under discussion at the end of that century (Fayolle, 2012). But more generally, between 1792 and 1793, the existing schools were shut down, with the banning of religious congregations and the subsequent suppression of academies, military schools, universities. Since Germain had only sisters and we have no evidence to the contrary, she was unlikely to have had private preceptorship. ${ }^{8}$ According to Libri, she became passionate about mathematics by reading Montucla's famous Histoire des mathématiques, and especially by the story of Archimedes' life. She would have started studying several mathematical books in her father's library, starting with Étienne Bézout's Cours de mathématiques, then an important reference textbook (Alfonsi, 2008). Her parents then worked hard to dissuade her from immersing herself in mathematics, considered useless or even dangerous for women. The scientific literature then intended for amateurs and especially for women, which had been booming for several decades, only exceptionally included calculations or mathematical tools, favoring a qualitative approach to astronomical or physical knowledge, for example (Peiffer, 1991).

In general, before the Revolution, the share of the mathematical and physical sciences was extremely small in the colleges; the situation changed with the creation of the Ecole polytechnique in 1794. Nevertheless, Germain, then aged 18, could not be admitted to this new institution reserved for men. Using Le Blanc, the name of a Polytechnic student apparently resigning, she managed to obtain the content of the lessons of some teachers, including Antoine-François Fourcroy (1755-1809) and Joseph-Louis Lagrange (1736-1813). She even succeeded in establishing a form of exchange with Lagrange, relying on the polytechnic custom that students pass on written notes on their lessons to

\footnotetext{
6 "bourgeoisie libérale et instruite".

7 (Szramkiewicz, 1974). Szramkiewicz indicates that Germain's father is often wrongly presented as director of the Banque de France.

${ }^{8}$ In some cases, a woman could benefit from private lessons given to a brother to acquire a learned culture (Peiffer, 1991, p. 198).
} 
teacher (Stupuy, 1879, p. 12). Impressed by the quality of the comments of the student Le Blanc, Lagrange wanted to meet him and thus learned the true identity of his interlocutor. This event allowed Germain to enter into contact with several of the most recognised mathematicians of that time.

\section{II.2 First Exchanges with the Academic Community and Germain's Mathematical Work}

This first meeting with Lagrange allowed the introduction of Germain into the learned community: many scholars of the time wanted to meet and support her. Traces remain from exchanges with Jacques Antoine Joseph Cousin (1739-1800), author of popular Leçons de calcul différentiel et de calcul intégral, the physician and agronomist Henri-Alexandre Tessier (1741-1837), the astronomer Jérôme Lalande (1732-1807), and the Hellenist Jean-Baptiste Gaspard d'Ansse de Villoison (1750-1805) (Bucciarelli, 1980, ch. 2). Her status as a young, self-taught woman in mathematics, regularly emphasised by her interlocutors, played an important role in these different relationships.

In connection with several recognised mathematicians, including Adrien-Marie Legendre (17521833), Carl Friedrich Gauss (1777-1855), Libri and Joseph Fourier (1768-1830), Germain joined into scholarly networks while remaining unmarried and without the assistance of a man from her family. This was very unusual for a woman at the time, noticed by some of her contemporaries. The consideration of this specific trait of Germain as a woman mathematician was for example reflected in the statement by Jean-Baptiste Biot (1774-1862), when Germain's first memoir was read as part of the Académie des sciences award in 1812: "The opening of the sealed note, made known the name of a woman, M.lle Germain, probably the person of her sex who penetrated the deepest in mathematics, without excluding M.me Du Chatelet; because here there was no Clairault." ${ }^{9}$ Germain participated actively in the construction of her image as an autonomous woman mathematician, far from the image of the "learned woman" as she wrote in one of her letters to Gauss for example, when she told him that she was Le Blanc:

[...] this circumstance determines me to confess to you that I am not so completely unknown to you as you think; but that, fearing the ridicule attached to the title of learned woman, I formerly borrowed the name of Mr. Le Blanc to write to you, and to give you notes which, undoubtedly, did not deserve the indulgence with which you were kind enough to answer them. ${ }^{10}$

It was precisely the aristocratic women of the salons (participants, organisers) who had links with science under the Ancien Régime. Next to the image of "learned woman" generally negatively connoted, worldly science ("science mondaine") was also strongly criticised during the revolutionary period (Chappey, 2004). Germain also reacted vividly to those who tried to flatter her, like Lalande when he wished to send her one of the copies of his Astronomie pour les dames, one of his books devoid of mathematical formulas.

Germain had two areas of predilection in mathematics: theory of elasticity and number theory. On the theory of elasticity, she was rewarded by the Académie des sciences in 1816. Nevertheless, Germain had to submit three different versions of her memoir initially submitted in 1812 because academicians criticised her mathematical errors, her formulation of analytical methods and some of them were maybe against the fact that she did not adopt the molecular approach. Analysis was taught at the École polytechnique, and Germain's weakness in this domain seemed to have been a cause of the errors contained in her early work on the theory of elasticity (Bucciarelli, 1980; Dahan Dalmedico, 1987). She began to work on number theory in early nineteenth century and rapidly mastered the most recent arithmetical writings, by Legendre and Gauss. Even if she corresponded with Gauss about

\footnotetext{
9 "L’ouverture du billet cacheté, fit connoître le nom d'une femme, M.lle Germain, probablement la personne de son sexe qui ait pénétré le plus profondément dans les mathématiques, sans en excepter M.me Du Châtelet ; car ici il n'y avait point de Clairault."

10 “[...] cette circonstance me détermine à vous avouer que je ne vous suis pas aussi parfaitement inconnue que vous le croyez: mais que, craignant le ridicule attaché au titre de femme savante, $j$ 'ai autrefois emprunté le nom de Mr. Le Blanc pour vous écrire et vous communiquer des notes qui, sans doute, ne méritaient pas l'indulgence avec laquelle vous avez bien voulu y répondre." (Del Centina and Fiocca, 2012, p. 669)
} 
number theory as early as 1804 , Germain only published one short note on the subject, in Crelle's Journal. One of her theorems was also included in one of Legendre's works on number theory in 1823. She also wrote some texts in philosophy that were recognised by Auguste Comte (1798-1857) and published by her nephew after her death. She died in 1831 of cancer as a "rentier" according to her death certificate.

\section{Sophie Germain and Number Theory, 1800-1830: Results and Practices}

It is well-known that, beyond solitary study, the scholarly production of a scientist depends on the scholarly and social networks in which he or she evolves (Govoni, 2000). In the case of Germain and number theory, it is thus important to know who produced and published number theory in the early nineteenth century; what mathematical training was needed; what role could discriminatory institutional mechanisms have in number theoretic work; what were the possible practices and modes of circulation for number theory; ${ }^{11}$ and how can Germain's work be analysed in this context.

\section{III.1 A Panorama of Number Theory from the 1800 s to the 1830 s}

The early nineteenth century was a transitional period for publications. Indeed, in 1805, the available publication outlets for mathematics were few and far between. Academic periodicals were difficult to access for non-academics, and scholarly journals such as the Journal des sçavants did not contain any articles on number theory. Books were also expensive to publish, and sales depended on limited spe- cialised sellers. For example, the number of publications including mathematical reasonings about congruences, ${ }^{12}$ introduced by Gauss in 1801 in his Disquisitiones arithmeticae (DA), was limited (30 texts between 1801 and 1825, many of which were actually algebra treatises, as those by Sylvestre-François Lacroix [1765-1843] and Peter Barlow [1776-1862] (Barlow, 1811; Lacroix, 1804), in which congruences were used very briefly). The number of publications including congruences increased from 1825 when new mathematical and scientific journals were created ( 224 texts between 1826 and 1850, of which only 17 were not included in periodicals) (Boucard and Verdier, 2015). In fact, Germain seems to be the only woman who published on number theory in the first half of the nineteenth century.

At the turn of the nineteenth century, two treatises on number theory appeared: Legendre's Essai sur la théorie des nombres (Legendre, 1798) and Gauss's DA (Gauss, 1801). Three points should be highlighted here. First, Legendre and Gauss had divergent opinions on the definition of number theory. Legendre identified number theory with indeterminate analysis. Gauss explicitly distinguished between these two domains, proposing number theory as being the domain where integer and rational numbers were considered, and not limited to equations. Second, in his book, Gauss gave a coherent presentation of number theory by organising it around two fundamental objects: congruences and quadratic forms. He gave two different proofs of the quadratic reciprocity law and a method to resolve the binomial equation $x^{p}=1$ algebraically by reindexing the roots with a primitive root of $p$, insisting on the links existing between different parts of his work and different mathematical domains, such as algebra and number theory. Third, Legendre's and Gauss's books were fundamental references for anyone planning to study number theory. Indeed, at the time, French teaching programs were focused on engineering, especially with the École polytechnique, and number theory was not taught at all. That is why if someone, male or female, wanted to study this domain, he or she had to read former publications, and especially Legendre's and Gauss's books.

\footnotetext{
11 This series of questions is inspired by (Gardey, 2005, pp. 31-32).

${ }^{12}$ Two numbers $a$ and $b$ are said congruents modulo a third number $p$ if $a-b$ is divisible by $p$. Gauss noted this relation $a \equiv b(\bmod p)$. The purpose of taking congruences as a marker for studying number theory in the first half of the nineteenth century and the constitution of the corpus from which these results were obtained is explained in (Boucard, 2011, chap. 1).
} 
Apart from several memoirs on Gauss sums, reciprocity laws and complex integers published by Gauss after 1801, DA were mostly used for the algebraic resolution of binomial equations before 1825. Between the 1820 s and the 1860 s, new scholars read Gauss' $D A$ and published arithmetical papers linked to it. In addition, evolutions in other mathematical areas, such as the use of complex numbers, Fourier analysis or elliptic functions, were applied in number theory. Historians C. Goldstein and N. Schappacher showed that a research domain they called Arithmetic Algebraic Analysis was then developed by an international network of scholars (Goldstein and Schappacher, 2007). But, at Germain's time, the use of analysis in number theory was marginal and Germain's potential weakness in analysis did not constitute a significant limitation. Within French number-theoretic production, there was multiform activity based on a strong link between equations and congruences. Specific problems were discussed such as the imaginary roots of congruences (by Louis Poinsot (1777-1859), Victor-Amédée Lebesgue (1791-1875), Évariste Galois (1811-1832), Germain), the number of integer roots of a congruence (by Libri, Lebesgue) or Fermat's Last Theorem (FLT) (by Legendre, Libri, Germain) (Boucard, 2015). These publications had common roots with Lagrange's and Legendre's arithmetical approach and integrated Gauss's objects and methods in varying proportions.

\section{III.2 Germain’s Arithmetical Traces: Publications, Manuscripts and Correspondence}

As Gauss observed in his correspondence, Germain was precisely one of the first mathematicians who mastered the contents of Gauss's $D A$ and who applied the theory of congruences to her numbertheoretical work. Moreover, after she impressed Lagrange with her mathematical skills, she became progressively close to mathematicians such as Gauss, Legendre, Augustin Louis Cauchy (1789-1857), Poinsot or Libri. Germain also met Carl Gustav Jakob Jacobi (1804-1851) and Galois. These mathematicians were the main authors who published on number theory at her time. Yet Germain only published one arithmetic note in Crelle's Journal in 1831 on cyclotomy, as a result of Legendre's and her work on FLT in particular. This note tells us that Germain was familiar with some of the notation and vocabulary used by Gauss. Nevertheless, it gives us very little information about her arithmetic practices. Another published trace of Germain's number-theoretic contribution can be found in a memoir about FLT presented by Legendre in 1823 at the Académie des sciences and published in 1827 (Legendre, 1827) : Legendre attributed three propositions to "Miss Sophie Germain"13 concerning some specific prime factors $\theta=2 k n+1$ when studying the equation $x^{n}+y^{n}+z^{n}=0$, with $n$ is an uneven prime and $k$ an integer.

We must therefore turn to unpublished sources to better understand Germain's work in number theory: mostly her correspondence with Gauss (we actually know ten letters from Germain and four from Gauss, written between 1804 and 1829) and some of her manuscripts including those entitled " Remarques sur l'impossibilité de satisfaire en nombres entiers à l'équation $x^{p}+y^{p}=z^{p}$ " and "Démonstration de l'impossibilité de satisfaire en nombres entiers l'équation $z^{2(8 n \pm 3)}+y^{2(8 n \pm 3)}=$ $z^{2(8 n \pm 3) " 14}$

From this corpus of texts, we get a good idea of her readings in number theory. Not only did Germain seem to read Legendre's and Gauss's books (Gauss, 1801; Legendre, 1798) as soon as they were published and to quickly appropriated their content, but she also studied the few arithmetic publications as they appeared, or even before: she took notes about a treatise by Barlow (Barlow, 1811), she received memoirs by Gauss (see below) or Poinsot. ${ }^{15} \mathrm{I}$ also found notes by Germain entitled "De

\footnotetext{
13 "Mle Sophie Germain" (Legendre, 1827, p. 17).

${ }^{14}$ The manuscripts are held in the Bibliothèque nationale de France in Paris and the Biblioteca Moreniana in Florence. Several letters can also be found in those libraries and in the Staats- und Universitätsbibliothek in Göttigen. The correspondence between Germain and Gauss is reproduced in (Del Centina and Fiocca, 2012) and some letters from Germain to Libri, Poinsot, Lagrange and Legendre are transcribed in (Del Centina, 2005). Germain's arithmetic manuscripts are partially or fully reproduced and commented in (Del Centina, 2008; Laubenbacher and Pengelley, 1999; 2010).

${ }^{15}$ In a letter to Poinsot dated July 2, 1819, Germain thanked him for a memoir he sent to her before its publication (Poinsot, 1820).
} 
l'équation $x^{5}+y^{5}=2^{a} z^{5}$ " about a memoir by Gabriel Lamé (1795-1870) which was apparently never published but might have been presented to the Académie des sciences. ${ }^{16}$ She studied mostly themes developed in the $D A$ - quadratic, cubic and biquadratic residues, cylclotomy and quadratic forms - and worked on the FLT.

Germain thus had access to and studied extensively arithmetic publications from the beginning of the century. These allowed her to acquire the necessary level of expertise to produce original research in number theory. As will be highlighted in the next subsection, these readings shaped her arithmetic work. This and the known exchanges she had with Gauss, Legendre, Libri or Poinsot show that she was well integrated into the arithmetic networks of her time. The fact that she worked in number theory in the 1810s and 1820s was also recognised by several scholars. Antoine-Augustin Cournot (1801-1877) for example mentioned her in his account of (Legendre, 1827) published in 1828 in the Bulletin de Férussac.

\section{III.3 Epistolary Exchanges Between Two Mathematicians in Number Theory: Gauss and Ger- main (1804-1829)}

In her first letter to Gauss, dated November 21, 1804, Germain showed that she was familiar with the concepts, notations and methods of Gauss. She quoted $D A$ several times, used Gauss' notation for congruences and cyclotomy and proposed several number-theoretic propositions: a generalisation of a theorem stated by Gauss in the 7th section, a new proof for the quadratic residue behaviour of 2 and a statement about a particular case of FLT. But from the first answer by Gauss, June 16, 1805, we find an imbalance in the correspondence between the two mathematicians: he warmly congratulated Germain for her new proof of the quadratic residue behaviour of 2 but he did not comment on her other arithmetic propositions. Gauss emphasized the fact that he had no time to pursue his research in number theory, monopolised as he was by his astronomical occupations. Table 1 shows that Gauss and Germain exchanged mathematical results, proofs and methods as well as memoirs, books, and personal news. Here I chose three examples to highlight the nature of the mathematical exchanges between Gauss and Germain.

In 1807, Gauss learned of Germain's true identity. In the letter dated February 20, 1807, Germain justified her use of a pseudonym and added an arithmetic note containing four results on numbers of the form $x^{2}+n y^{2}$, , numbers that had been the subject of previous research by Leonard Euler (1707-1783), Lagrange, Legendre and Gauss for example. In his reply of April 30, 1807, Gauss noticed that some of her conjectures were false, including the following: if the sum of two $n$-th powers is of the form $b^{2}+n f^{2}$, then the sum of the two numbers is of that form as well. ${ }^{17}$ Gauss illustrated with a counterexample: $15^{11}+8^{11}=8658345793967=1595826^{2}+11 \cdot 745391^{2}$ but $15+8=23 \neq x^{2}+11 y^{2}$. First, Gauss expressed the pleasure he had reading Germain's note and was careful not to upset her:

The learned notes, of which all Your letters are so richly filled, have given me a thousand pleasures. I have studied them attentively, and I admire the ease with which you have penetrated all the branches of Arithmetic, and the sagacity with which You have been able to generalise and perfect them. I beg You to consider as a proof of this attention, if I dare to add a remark to a place of Your last letter. ${ }^{18}$

It is interesting that Gauss took the time to find a non-trivial large counterexample: he used several methods he developed in $D A$ in order to calculate what seems to be the smallest counterexample

\footnotetext{
${ }^{16}$ On her notes, she added "Notes prises du mémoire de M. Lamé" (Bibliothèque nationale de France, Département des manuscrits, Manuscript FR 9114, f. 156-161). Lamé's memoir may be the work he submitted on the occasion of the Académie prize concerning the FLT in 1818 (Goldstein, 2009).

17 "si la somme des puissances $n$-ièmes, de deux nombres quelconques est de la forme $b^{2}+n f^{2}$ la somme de ces deux nombres eux-mêmes sera de la même forme."

18 "Les notes savantes, dont toutes Vos lettres sont si richement remplies, m’ont donné mille plaisirs. Je les ai étudiées avec attention, et j'admire la facilité avec laquelle vous avez pénétré toutes les branches de l'Arithmétique, et la sagacité avec laquelle Vous les avez su généraliser et perfectionner. Je Vous prie d'envisager comme une preuve de cette attention, si j'ose ajouter une remarque à un endroit de Votre dernière lettre." (Del Centina and Fiocca, 2012, p. 672)
} 
Table 1 - List of known letters between Germain and Gauss, from (Del Centina, 2005; Del Centina and Fiocca, 2012). "FLT" is for "Fermat's Last Theorem". Gauss' references can be found in the bibliography.

\begin{tabular}{|c|c|c|c|}
\hline Date & Sender & Recipient & $\begin{array}{l}\text { Main discussions about Number the- } \\
\text { ory }\end{array}$ \\
\hline $1804 / 11 / 21$ & Le Blanc & Gauss & $\begin{array}{l}\text { Sec. } 7 \text { of (Gauss, 1801), FLT (exp. } p- \\
1, p=8 k+7), 2 \text { as a quadratic residue, } \\
\text { variety of proofs }\end{array}$ \\
\hline $1805 / 06 / 16$ & Gauss & Le Blanc & $\begin{array}{l}2 \text { as a quadratic residue, No time, Book- } \\
\text { seller }\end{array}$ \\
\hline $1805 / 07 / 21$ & Le Blanc & Gauss & $\begin{array}{l}\text { Quadratic forms, power residues, gen- } \\
\text { eralisations }\end{array}$ \\
\hline $1805 / 08 / 20$ & Gauss & Le Blanc & Sending (Gauss, 1799) \\
\hline $1805 / 11 / 16$ & Le Blanc & Gauss & Quadratic forms \\
\hline $1807 / 02 / 20$ & Germain & Gauss & $\begin{array}{l}\text { Cyclotomy, discussion about her iden- } \\
\text { tity }\end{array}$ \\
\hline $1807 / 04 / 30$ & Gauss & Germain & $\begin{array}{l}\text { Counter-example to explain an error } \\
\text { by Germain, No time, Results on cu- } \\
\text { bic and biquadratic residues to prove }\end{array}$ \\
\hline $1807 / 06 / 27$ & Germain & Gauss & $\begin{array}{l}\text { Proofs of Gauss' theorems \& generali- } \\
\text { sations }\end{array}$ \\
\hline $1808 / 01 / 19$ & Gauss & Germain & $\begin{array}{l}\text { Göttingen, Congratulations, Work on } \\
\text { cubic and biquadrtic residues, sending } \\
\text { (Gauss, 1808) }\end{array}$ \\
\hline $1808 / 03 / 19$ & Germain & Gauss & $\begin{array}{l}\text { Proof of a result of (Gauss, 1808), For- } \\
\text { wards Legendre's thanks }\end{array}$ \\
\hline $1809 / 05 / 22$ & Germain & Gauss & $\begin{array}{l}\text { Thanks for (Gauss, 1811), } 2 \text { as a bi- } \\
\text { quadratic residue, questions about pos- } \\
\text { sible generalisation of reciprocity law }\end{array}$ \\
\hline $1809 / 05 / 26$ & Germain & Gauss & Thanks for his astronomical treatise \\
\hline $1819 / 05 / 12$ & Germain & Gauss & $\begin{array}{l}\text { Sending of [Poinsot1820], Comments } \\
\text { on (Gauss, 1818; Poinsot, 1820), cubic } \\
\text { and biquadratic residues, FLT }\end{array}$ \\
\hline $1829 / 03 / 28$ & Germain & Gauss & Thanks for (Gauss, 1828) \\
\hline
\end{tabular}


for $\mathrm{n}$ prime and two co-prime numbers for the $n$-th powers (MacKinnon, 1990; Waterhouse, 1994). Gauss also explained to Germain why another of her propositions was not true by using his theory of quadratic forms.

In this same letter, he also announced his progress on the theory of cubic and biquadratic residues. Gauss gave the statement of three propositions on the cubic residue behaviour of \pm 2 for prime numbers of the form $3 n+1$, on the biquadratic residue behaviour of \pm 2 for prime numbers of the form $8 n+1$ and on quadratic residues without any proof. Germain responded on June 27, 1807, and proposed a proof for each statement sent by Gauss. For cubic and biquadratic residues, she used a method she found in the 7th section of $D A$. She also submitted to Gauss new similar statements. When Gauss answered to Germain in January 1808, he did not comment precisely on her work, but he had written in July 1807 to Wilhelm Olbers (1758-1840), enthusiastic after he read Germain's letter:

Lagrange still shows great interest in astronomy and higher arithmetic; he considers the two theorems (for which primes 2 is a cubic or a biquadratic residue) which I told you about some time ago, 'what one can have that is most beautiful and difficult to prove'. But Sophie Germain has sent me the proofs of them; although I have not yet been able to look carefully through them, I think they are good, at least she has approached the problem in the right direction; they are only somewhat longer than they need be. ${ }^{19}$

So Gauss appreciated the arithmetic exchanges he had with Germain, with whom he could discuss on the main arithmetic subjects in $D A$ and in his further research: quadratic, cubic and biquadratic residues, quadratic forms and cyclotomy. On the other hand, although Germain referred to FLT as early as 1804, it seems that Gauss never gave her any feedback on this question. A possible explanation of this non-reaction is that Gauss was simply not interested by Fermat's equation, as he wrote to Olbers in 1816 when FLT was the subject of the Grand prix at the Académie des sciences:

I am very much obliged for your news concerning the [newly established] Paris prize. But I confess that Fermat's theorem as an isolated proposition has very little interest for me, because I could easily lay down a multitude of such propositions, which one could neither prove nor dispose of. ${ }^{20}$

Some general features emerge from this correspondence. Through her studies and her connections with mathematicians, Sophie Germain had a great mastery of Gauss' arithmetic work and, more generally, of the number-theoretic research of her time. Gauss admired her arithmetic skills very much and seemed to consider her as a full-fledged colleague in their exchanges, although he never had much time to pursue his arithmetical research or to write to her at greater length. Let us note that Gauss is not the only mathematician who asked Germain to prove an arithmetical claim: according to one of Germain's manuscript, Lagrange also asked her to prove a result about triangular numbers (Alexanderson, 2012).

\section{III.4 Germain's Arithmetical Practices and Program: the Case of Fermat's Last Theorem}

Germain's known result about FLT is the one published in the memoir of Legendre, Recherches sur quelques objets d'analyse indéterminée et particulièrement sur le théorème de Fermat presented to the Académie des sciences in 1823 and published in 1827:

\footnotetext{
19 "Lagrange interessirt sich noch mit vieler ärme für die Astronomie und höhere Arithmetik; die beiden ProbeTheoreme (in welchen Primzahlen 2 ein kubischer oder ein biquadratischer Rest ist) die ich auch Ihnen vor einiger Zeit mittheilte, hält er für "ce qu'il peut y avoir de plus beau et de plus difficile à démontrer." Aber die Sophie Germain hat mir die Beweise derselben geschickt; noch habe ich sie zwar nicht durchgehen können, ich glaube aber, dass sie gut sind; wenigstens hat sie die Sache von der rechten Seite angegriffen, nur etwas weitlaüfiger sind sie als nöthig sein wird "(Del Centina and Fiocca, 2012, p. 627)

20 "Für Ihre Nachrichten, die Pariser Preise betreffend, bin ich Ihnen sehr verbunden. Ich gestehe zwar, daß das Fermat'sche Theorem als isolirter Satz für mich wenig Interesse hat, denn es lassen sich eine Menge solcher Sätze leicht aufstellen, die man weder beweisen, noch widerlegen kann." The translation is from (Laubenbacher and Pengelley, 2010).
} 
For an odd prime exponent $p$, if there exists an auxiliary prime $\theta$ such that there are no two nonzero consecutive $p$-th powers modulo $\theta$, nor is $p$ itself a $p$-th power modulo $\theta$, then in any solution to the Fermat equation $z^{p}=x^{p}+y^{p}$, one of $x, y$, or $z$ must be divisible by $p^{2}$.

Legendre explicitly credited Germain with this theorem and the table where she verified the existence of an auxiliary prime for all primes $p$ less than 100 . For numerous $p$, this theorem gives a way to prove the first case of FLT, namely to prove there is no integer and nonzero solutions prime to $p$. This theorem constituted the first published attempt for a general result concerning FLT. Indeed, before Ernst Kummer (1810-1893)'s work in the 1840s, only three cases (for $p$ prime) exponents were proved: 3 (Euler), 5 (Legendre and Dirichlet) and 7 (Lamé). ${ }^{21}$

From Germain's manuscripts and the letters she exchanged with Gauss, ${ }^{22}$ we know that Germain had a more ambitious plan to prove FLT, initiated at least in 1804. She tried to construct a proof for whole families of exponents - contrary to Legendre or Johann Peter Gustav Dirichlet (1805-1859), who obtained proofs for a single exponent - and she imagined a plan to prove FLT in general.

In 1819, she explained the "metaphysics" of her method to Gauss:

The order in which the residues (powers equal to the exponent) are distributed in the sequence of natural numbers determines the necessary divisors which belong to the numbers among which one established not only the equation of Fermat, but also many other analogous equations. ${ }^{23}$

Congruences and roots of unity were fundamental in her plan which utilised her precise knowledge of Gauss's work. In the above quotation, she also insisted on the importance of the order "in which the residues are distributed". She attributed this "metaphysics" of the method to another French mathematician, Poinsot, who presented his paper about algebra and number theory "Mémoire sur l'application de l'algèbre à la théorie des nombres" at the Académie des sciences in 1818. As mentioned before, she also wrote a letter to Poinsot in 1819 to thank him for sending her his memoir - which was later published, in 1820 - and to congratulate him for his use of imaginary roots of congruences and for his reflections on the different orders that can be obtained from the consideration of the roots of certain congruences. This highlights yet again that Germain had access to some of the latest number-theoretical research, which she studied attentively.

Germain's method is indeed based on an analogy between equations and congruences and on the order of the residues of $p$-th powers modulo a prime $\theta$. If the equation $x^{p}+y^{p}=z^{p}$ ( $p$ prime) has a nonzero solution, then for every prime $\theta$, the congruence $x^{p}+y^{p} \equiv z^{p}(\bmod \theta)$ also has a nonzero solution. But, if $x$ is not divisible by $\theta$, there exists an inverse of $x$ modulo $\theta$, namely a number $k$ such that $1+(k y)^{p} \equiv(k z)^{p}(\bmod \theta)$. In that case, a new congruence can be found and it follows that there must exist some nonzero consecutive $p$-th power residues. Germain's idea to prove FLT for a given $p$ was to show that there exists an infinity of $\theta$ : it would mean that $x-$ or $y$, or $z-$ is divisible by an infinity of prime numbers, which is impossible.

But, as Germain soon observed, her plan could not succeed because some of the p's are such that there is not an infinitude of $\theta$ s. But, although Germain's plan did not succeed, she showed really impressive skills in calculation, obtained general results on FLT, and managed to show that the potential solutions of certain cases should be of a very big size, as she wrote to Gauss in 1819:

I have never been able to arrive at infinity, although I have pushed back the limits quite far by a method of trials too long to describe here [...] You can easily imagine, Monsieur, that I have been able to succeed

\footnotetext{
${ }^{21}$ On the history of FLT, see for example (Corry, 2010; Edwards, 1977).

${ }^{22}$ As mentionned before, a detailed study of Germain's work on FLT is given in (Del Centina, 2008; Laubenbacher and Pengelley, 2010).

23 "L'ordre dans lequel les résidus (puissances égales à l'exposant) se trouvent placés dans la série ds nombres naturels détermine les diviseurs nécessaires qui appartiennent aux nombres entre lesquels on établit non seulement l'équation de Fermat, mais encore beaucoup d'équations analogues à celles-là." (Del Centina and Fiocca, 2012, p. 690)
} 
at proving that this equation is not possible except with numbers whose size frightens the imagination $[\ldots]^{24}$

These different facts underline several interesting points regarding Germain's status in number theory at that time: the content of her work lay both in the line of arithmetic work on indeterminate equations and based on a contemporary analogy between equations and congruences (Legendre, Poinsot, Libri or Cauchy) and integrated tools, methods and results of $D A$. She was indeed quite familiar with those publications and connected to the mathematicians who published them. So if, as a woman, she could not be taught or attend scientific institutions, the marginal status of number theory at the beginning of the nineteenth century and the fact that it was not taught in the École polytechnique, for example, meant that her gender stigmatised her less than other mathematical domains. Every mathematician wishing to study number theory had to study the same texts as Germain (Gauss' and Legendre's writings mostly) and the minuscule number of amateurs in num- ber theory certainly allowed her to have privileged contact with Gauss. Thus, the exclusion of women from academic spheres seems to have been less disabling for studying number theory: the specific mathematical culture transmitted in an institution such as the École polytechnique seems to have been less of a problem for Germain in the case of number theory than for the theory of elasticity. Furthermore, being a woman from the bourgeoisie certainly facilitated her access to scholarly networks compared to a man of a lower social class who did not attend institutions such as the École polytechnique.

Nevertheless, Germain never directly published her results on FLT. Maybe it was because she knew that she did not succeed in achieving her grand plan. As a woman, she did not have access to some institutions that made it easier to publish mathematical research, as for example the École polytechnique and its Journal. But, more generally, the possibilities of publishing an article in number theory outside of an academic framework were relatively small until the end of the 1820 s, or even the 1830s. Indeed, another mathematician of her time, Lebesgue, whose work was mainly concerned with number theory but who was neither a polytechnician nor an academician, was only able to regularly publish his arithmetical memoirs as of 1836, in the Comptes-rendus de l'Académie des sciences and in the Journal de mathématiques pures et appliquées, created in 1835 and 1836 respectively.

\section{Germain’s “ Second Life” : Some Appropriations of Germain’s Life and Work After Her DeATH}

If Germain was periodically quoted for the content of her mathematical and philo- sophical work, her status as a woman mathematician was often mobilised to nourish the debates on the woman question under the French Third Republic in particular. This part is a first attempt to analyse how the figure of Germain entered the history of science and was used in the discourses on science and women in France from her death in 1831 to the 1910s. For this, I collected some two hundred references to Germain in French publications published from the death of Germain until the early 1930s and available on several digital databases. ${ }^{25}$ These sources show multiple images of the life and work of Germain mainly in France under the Third Republic. Through Germain, we can see how a woman mathematician, a professional scholar who was different, even opposite to the models of the woman

\footnotetext{
24 “Je n’ai jamais pu arriver à l'infini quoique j'ai reculé bien loin les limites par une méthode de tâtonnement trop longue pour qu'il me soit possible de l'exposer ici. [...] Vous concevrez aisément, Monsieur, que j'ai dû parvenir à prouver que cette équation ne serait possible qu'en nombres dont la grandeur effraye l'imagination [... ]" (Del Centina and Fiocca, 2012, p. 691). Translation is from (Laubenbacher and Pengelley, 2010).

${ }^{25}$ I used mainly Google Books, Gallica, Numdam and the Jahrbuch database. By the nature of these databases and the way the texts are digitalised, the result cannot be considered an exhaustive and precise quantitative study. But this study of Germain's receptions has the merit of highlighting several uses of Germain's narrative in contemporary debates on women and mathematics in particular.
} 
then in force, was used as an example or a counter-example to fuel the debates on women, their education and their position in French society. ${ }^{26}$

Beyond the reception of her work, Germain was mentioned very regularly in the revival of debates on the question of women from the 1840s at least. Indeed, as early as the 1820s, many authors came back to the social demands of the Enlightenment, especially those concerning the place of women in society. In a context of significant literacy, the development of state education and instruction, the beginning of industrialisation (and therefore the emergence of the figure of the working-class woman), and the question of creating public education for girls (thus countering the Church's monopoly) was regularly debated. During this period, Utopian movements, such as the Saint-Simonians, began to claim rights for women. It was also the century of the "Civilisation of the journal" (Kalifa et al., 2011): the rise of the newspaper and journals was particularly important in the nineteenth century, in all areas. I already mentioned scientific and mathematical journals. This was also the case for the press dedicated to specific categories of the population. For example, the women's journal La Femme nouvelle was created in 1832 on the initiative of several Saint-Simonians. First feminine then feminist presses developed throughout the century. Nevertheless, women's rights advocates practically never claimed absolute equality between men and women; they defended the complementarity of the sexes, which would not necessarily be hierarchical and associated with separate private spheres (feminine) and public spheres (masculine). Moreover, in post-revolutionary France, family prevailed as a basic socio-political unit in society. This postulate of a fundamental difference between the sexes was generally shared throughout Europe by the defenders and detractors of women's rights during the nineteenth century. An emblematic illustration of this was the theory of Ernest Wilfred Legouve (1807-1903), summed up by the motto "equality in difference". It was the leitmotif of the Republican movement of the late 1840s and Republican politics under the Third Republic in France (Offen, 1986; 2018).

\section{IV.1 Mathematical, Philosophical and Material Memories of Germain}

After Germain's death in 1831, Libri's eulogy and the publication of her philosophical work by her nephew, some biographies can be found in the 1830s and 1840s in biographical dictionaries. She was then described as one of the creators of mathematical physics; there were sometimes references to her philosophical writings but her work in number theory was generally hardly mentioned. For several reasons, it was mostly from the 1870s that Germain's number-theoretical and philosophical achievements were regularly quoted.

Before 1870, occasional references to her scientific research were made in scholarly periodicals. An example can be found in the Nouvelles annales de mathématiques, a French mathematical journal published from 1842 to 1927, dedicated to teachers and students (candidates to polytechnic and normal schools at first). It contained mathematical articles, mathematical questions and answers sent by the editors and readers, but also biographical and bibliographical reviews and texts. As chief editor of the journal, Olry Terquem (1782-1862) mentioned Germain at least three times between 1857 and 1861. In 1857, below the answer to a mathematical question by a certain "Mlle Adolphine D", he noted that five French women succeded in mathematical studies: Marie Crous (17th century), Jeanne Dumée (16601706), "la célèbre marquise du Châtelet", Hortense Lepaute (1723-1888) and Germain, "laureate of the Académie des sciences for the very difficult question of the vibrating plates". ${ }^{27}$ After Joseph Bertrand (1822-1900) announced the deposit of Germain's manuscripts to the Académie des sciences ${ }^{28}$ Terquem published in 1860 a 4-page biography of Germain where he mentioned her "epistolary exchange with

\footnotetext{
${ }^{26}$ Compared to The Many Lives and Deaths of Sofia Kovalevskaya by Katharina Rowold(Rowold, 2001), I also use the references to Germain to study discourses on the woman question but in a different national context, from different initial features of the woman mathematician (Germain was not able to get a higher education or an academic position, she was single her whole life and the institutional and scientific contexts were different). Thanks to digital databases and recent secondary literature such as (Kalifa et al., 2011; Offen, 2018), I also was able to take into account the writings published in the daily and specialised press.

27 "lauréat de l'Académie des sciences pour la question très-difficile des plaques vibrantes".

${ }^{28}$ Comptes rendus hebdomadaires des séances de l'Académie des sciences, vol. 49, p. 45, 1859.
} 
Gauss" 29 and Germain's new theorems in number theory published by Legendre ${ }^{30}$. The purpose of this biography was to introduce his review of Germain's philosophical work, which was to be published in 1861. As early as 1860, he highlighted the importance of finding and editing the correspondence between Gauss and Germain.

Epistolary exchanges between Gauss and Germain were then mainly rediscovered from the end of the 1870s, as Schering was preparing a volume of Gauss's collected papers. ${ }^{31}$ The content of their correspondence was vividly commented, especially to reconstitute the chronology of Gauss's work on cubic and biquadratic residues. Nevertheless, the arithmetical aptitudes of Germain were also recognised. For example, she was qualified as a "conscientious and competent reader" by the Belgian mathematician Paul Mansion (1844-1919):

The admiration expressed by Gauss, at the end as at the beginning of his letter, should not surprise us. Aside from Sophie Germain, nobody seemed to take an interest in the Disquisitiones, nor to dedicate to these the attention they deserved. It was natural that the young Hanoverian mathematician, still not very well known at that time, felt and expressed a strong pleasure at having found in Sophie Germain such a conscientious and competent reader. ${ }^{32}$

It seems that, from this period, Germain's work entered the history of number theory more vividly. If we take the example of two important books about the history of number theory, there was no citation of Germain's arithmetical writings in the Report on the Theory of Numbers published by Henry J. S. Smith (1826-1883) between 1859 and 1865 (Smith, 1859-1865) whereas they were mentioned several times in the History of the Theory of Numbers published by Leonard E. Dickson (1874-1954) between 1919 and 1923, in connection with FLT (Dickson, 1919-1923, vol. 2, 732-735) and the factors of $a^{n} \pm b^{n}$ (where $a, b, n$ are integers) (Dickson, 1919-1923, vol. 1, 382-383). Smith and Dickson did not have the same perspective when writing those texts. On the one hand, Smith compiled his report at the request of the British Association for the Advancement of Science so organised it according to the theory of congruences and the theory of forms, that is to say according Gauss's $D A$ structure (Goldstein and Schappacher, 2007, p. 55). On the other hand, for his History of the Theory of Numbers, Dickson studied an impressive number of publications and manuscripts. He had some difficulties finding money for the publication for his massive compendium, which was finally funded by the Carnegie Institution of Washington (Fenster, 2007). In his History, Dickson adopted an organisation centered on divisibility and diophantine analysis (which is the topic of the massive second volume). Beyond the facts that Germain's number-theoretical work was then better known and that Dickson was able to read some of her manuscripts and letters to Gauss, her results fitted better in Dickson's presentation. From the 1880s, Germain's number-theoretical work was also discussed from her correspondence with Gauss by several mathematicians such as Angelo Genocchi (1817-1889) and Mansion, for example, who promoted number theory in scholar societies as the Association française pour l'avancement des sciences or mathematical journals as Nouvelle correspondance mathématique. They belonged to a cluster identified in (Goldstein and Schappacher, 2007) where the authors were mostly engineers and high-school teachers, such as Genocchi or Édouard Lucas (1842-1891). They worked mainly on arithmetic questions already studied in Legendre's and Gauss's work. Like Germain, they approached these questions without using analysis: Germain's research was therefore close to their

\footnotetext{
29 "commerce épistolaire avec Gauss"

30 "En arithmologie, elle démontra des théorèmes nouveaux, que Legendre a admis dans son ouvrage." (Terquem, 1860, p. 12)

${ }^{31}$ References to Germain's work in connection with the publication of Gauss's works and the discovery of their correspondence are studied in (Del Centina and Fiocca, 2012).

32 "L'admiration que Gauss exprime ainsi, à la fin comme au début de sa lettre, ne doit pas nous étonner. À part Sophie Germain, personne ne semblait, en effet, s'occuper des Disquisitiones ni leur accorder l'attention dont elles étaient dignes. Il est tout naturel que le jeune Géomètre hanovrien, encore peu connu à cette époque, éprouvât et exprimât un vif contentement d'avoir trouvé, en Sophie Germain, un lecteur consciencieux et compétent."(Mansion, 1880, p. 219) Quotation and translation quoted from (Del Centina and Fiocca, 2012, p. 597).
} 
interests. During the 20th century, mathematicians also followed Germain's path and developed new results about FLT by using her results or methods, sometimes without knowing it. Her arithmetic work is now quoted in most books about the history of number theory and, as mentioned before, it has been the focus of whole studies by historians of mathematics.

Germain's philosophical writings also enjoyed renewed interest in the late 1870s. The positivist journalist Stupuy edited them in 1879, with an Étude sur la vie et les oenvres de Sophie Germain. Not only was Germain's philosophical thought debated by many philosophers and scholars, especially positivists, but her precise biography was put back on the scene. Indeed, according to Stupuy, the historical character of Sophie Germain was constructed especially from the last quarter of the nineteenth century. In 1879, he commented:

A painful confession must be made. While so many women have found fame in frivolous writings, the only French woman who has succeeded in hard work, was esteemed by math- ematicians, who, moreover, do not understand an entire aspect of her genius, is scarcely known to the public. (Stupuy, 1879, "Étude sur la vie et les œuvres de Sophie Germain") ${ }^{33}$

But, less than twenty years later, for the new edition of her philosophical works, Stupuy highlighted a radical change:

Sophie Germain has taken up this second life, which is made of the memory of the living: her work and her biography have conquered their place in the memory of humans; her tomb, abandoned, was found and restored; the Paris City Council, always concerned with Parisian glories, gave the name of Sophie Germain to one of the streets of the capital, to one of its girls' high schools, and her bust, reconstituted from to the phrenological head preserved at the Museum of Natural History, adorns the main courtyard of this school. In addition, a commemorative plaque was placed on the house where she died. (Stupuy, $1896)^{34}$

Indeed, with the (re)editions of Germain's scholarly work and the vivid debates concerning the role of women in society, Germain became a regular reference for scholars, journalists, etc. The publication of her philosophical memoirs was quoted and discussed in numerous articles. For example, Louis Liard (1846-1917), a philosopher known for the reform of the French university in 1896 named after him, published a review of Germain's Euvres philosophiques in the Revue philosophique de la France et de l'étranger (Liard, 1879) ; Doctor Second commented on the publication of Germain's philosophical writings in the positivist journal La Philosophie positive edited by Émile Littré (1801-1881) in October 1879. He also referred to Germain's philosophy in La Nouvelle revue in an article about biology teaching (Second, 1879). In April 1879, the architect and art historian Eugène-Emmanuel Viollet-Le-Duc (1814-1879), known for his rationalist approach to ornamental art and his writings with positivist tendency, published a text entitled "Sophie Germain”, celebrating Stupuy's edition, in the daily Republican newspaper Le XIX $x^{e}$ siècle. Considered a moderate Republican in the 1870s, Viollet-Le-Duc promoted an alliance between science and art as part of a "national, political and social regeneration" (Baridon, 2010). In his article about Germain, Viollet-Le-Duc selected quotes from her work to underline the fundamental importance of close relations between art and science rather than a reductive specialisation.

Beside comments and precise writings about Germain's philosophical and number- theretical work by scholars, mentions of Germain can be found in very different contexts. In the 1880s, she was

\footnotetext{
33 "Il faut en faire l'aveu pénible. Tandis que tant de femmes ont trouvé la célébrité dans les écrits frivoles, la seule femme française qui ait réussi dans les travaux sévères, estimée des géomètres, auxquels d'ailleurs tout un aspect de son génie échappe, est à peine connue du public.”.

34 "Sophie Germain a repris cette seconde vie qui est faite du souvenir des vivants : son œuvre et sa biographie ont conquis leur place dans la mémoire des hommes ; son tombeau, délaissé, a été retrouvé et restauré ; le Conseil municipal de Paris, toujours soucieux des gloires parisiennes, a donné le nom de Sophie Germain à l'une des rues de la Capitale, à l'une de ses écoles supérieures de jeunes filles, et son buste, reconstitué d'après la tête phrénologique qui existe au Museum d'histoire naturelle, orne la cour principale de cette école. De plus, une plaque commémorative a été aposée sur la maison où elle est morte."
} 
the subject of discussions about naming places and buildings, especially in the Paris city council. As a councilor of the ninth arrondissement of Paris from 1884 to 1893, Stupuy may actually have played a role in building a civic legacy of Sophie Germain in Paris. For example, in the 1880s, after numerous debates, the Paris city council voted to give the name of Sophie Germain to a Parisian street. In 1882, the first école primaire supérieure for girls, in 1882, was named after Germain, also after discussions in the Paris City Council. The Paris City Council also ordered a marble bust of Germain for the Sophie-Germain school. The traces of associated discussions can be found in the daily and weekly press. ${ }^{35}$ These debates show that Germain had gradually become a reference as a woman mathematician. These facts of her life were indeed used after her death, and especially from the 1870s, in the context of various subjects. This is the purpose of the following subsections.

\section{IV.2 Germain, a Woman Among Other Women in Mathematics and Science}

As a woman, Germain was also very often mentioned as a pioneer among other pioneers. Thus, references to Germain were very often made to celebrate remarkable achievements by a woman in mathematics: we already mentioned Terquem's text when he commented on the fact that a woman - Adolphine D. - answered to a question in the Nouvelles annales de mathématiques. Germain's biography was also summed up in numerous articles published at the time when Kovalevskaya attended the sessions of the Académie, ${ }^{36}$ won the Borda prize at the end of the $1880 \mathrm{~s}^{37}$ and died in $1891{ }^{38}$ The doctoral thesis obtained by Dorothea Klumpke (1861-1942) in 1893 was followed by articles on women and mathematics and the growing number of women studying in university. For example, in Le XIX siècle, André Balz (1845-1931), agrégé and docteur ès lettres, published a text entitled Les femmes et les astres in which he was ironic about the scope of Klumpke's astronomical research, "at a sidereal distance from contemporary utilitarianism". ${ }^{39}$ He also noted that if there already were several women who had a doctoral thesis in medicine, Klumpke was the first woman with a mathematical thesis that "has another scope and also this superiority that it can serve absolutely nothing". ${ }^{40}$ The debates about Marie Curie (1867-1934)'s possible election at the Académie des sciences was also the occasion for short notes and articles containing references to Germain in various journals. ${ }^{41}$

From the end of the nineteenth century, several collections of biographies of women in mathematics or women in science appeared in parallel with the rise of feminist movements (and antifeminist reactions). Among them, we can cite Les femmes dans la science by Alphonse Rebière (1842-1900) in 1894 and 1897, Weibliche wissenschaftliche Leistungen in den Gebieten Mathematik, Astronomie und Nautik by Georg Weyer in 1897, Les Femmes dans la science in 1909 by Maurice d'Ocagne (1862-1938), or Women in Science by H. J. Mozans (1851-1921) in 1913 (Renate et al., 2001, p. 27). More generally, in France, if mistrust of the activities of literate women under the Third Republic was slightly less than under the previous regime, the debates on (ab)normality of scholarly women were continuing. Articles, books on women writers, and some anthologies during the 1870s and 1880s were common. The first anthology edited by a woman seems to have been published in 1893, but a collection of biographies

\footnotetext{
${ }^{35}$ For example, beside the Bulletin de la ville de Paris, traces of debates about naming a Parisian street after Germain can be found in: Le XIX ${ }^{e}$ siècle (July, 30, 1882), Le Petit Parisien (July, 30, 1882), Le Petit journal (July, 30, 1882), Le Figaro (August, 28, 1882), Le Radical (August, 30, 1882) Journal des débats politiques et littéraires (August, 8, 1882), Le Passant (August, 5, 1882), etc.

${ }^{36}$ For example, Journal des débats politiques et littéraires (June 29, 1886).

${ }^{37}$ Journal des débats politiques et littéraires (December 11, 1888), Le Petit journal (December 29, 1888), or the bimonthly La Femme (vol. 11, no 3, 1889), created in 1879 and whose subtitile was sometimes "organe des institutions féminines, chrétiennes, sociales et de l'Union nationale des amies de la jeune fille".

${ }^{38}$ Among other references : Le Petit journal (February 17, 1891), Le Petit Parisien (February 18, 1891), La Croix (February 18, 1891).

39 “à une distance sidérale de l'utilitarisme contemporain".

40 “a une autre envergure et aussi cette supériorité qu'il ne peut servir absolument à rien”.

${ }^{41}$ For example: Le Figaro (January 3, 1911), La Paix sociale (February 2, 1911), L'action féminine. Bulletin officiel $d u$ conseil des femmes françaises (February, 1910) or Le Gaulois (February 8, 1922)
} 
of notable women, under the title Les femmes dans l'histoire, appeared in 1888 by Henriette de Witt (1829-1908), daughter of the former ministry of education François Guizot (Offen, 2018). De Witt used Germain and Mary Sommerville (1780-1872) as evidences in her arguments against the usefulness of higher education for women, as we will see later.

A work dedicated to women in science was introduced by the mathematics teacher Rebière in 1894. He was also involved in the contemporary debates on female education: in the 1880s, following the Camille Sée law (1880), which introduced public secondary education for young girls, Rebière had analysed the place of mathematics in the different classes of female secondary education (Hulin, 2008). In 1894, he gave a lecture in front of the Saint-Simon circle entitled "Les femmes et la science" 42 in which he presented the portrait of six women of science (Hypatia, du Châtelet, Maria Gaetana Agnesi (1718-1799), Germain, Sommerville, Kovalevskaya) and announced a more ambitious work on the same subject. The second edition of Les Femmes et la science appeared in 1897, and contained nearly 650 portraits of women engaged in some way in science and a collection of historical and contemporary quotes on women's ability in science. Note that apart from a summary of the different opinions on the question (Rebière, 1897, pp. 289-290), Rebière did not give his own opinion. Nevertheless, these women of science had been much in the news. The two books by Rebière were the subject of numerous reports and the starting point of articles on the question of women in science, in which his por traits were reproduced or summarised. Some authors used their review of Rebière's work to develop their own ideas on the issue; the reading of their writings reveals some trends of the time. Émile Fage (1822-1906), a member of the Société des lettres, sciences et arts de la Corrèze, used his review of (Rebière, 1894) to give his opinion on the life of women mathematicians. Thus, if Germain is one of the women who were "less light than the Marquise du Chatelet and less tormented than Sophie Kowalevski", the conclusion remained unchanged: "the learned women, even the happiest, have ignored the true happiness"(Fage, 1894, pp. 254-255). ${ }^{43}$ For Fage, a learned woman could not be happy because she was not able to find essential love, a spouse and a family (Fage, 1894, p. 253). The journalist (and future Republican deputy) Émile Cére (1863-1932) stated an opposite opinion from (Rebière, 1894). He wrote in Le Petit journal (22 september 1896) about his "women's academy of science" ("académie des sciences féminine"), of which Germain would be the president:

A woman who studies mathematics is she necessarily a bad housewife? No, she is not. Most of the scholars whom we spoke of were accomplished wives, excellent mothers, and those who will follow them in the career of the sciences will, we hope, have their domestic virtues, with their scientific merit. (Cére, $1896)^{44}$

These words refer to a central question debated at least since the beginning of the century: the fact that women's happiness was based on their domestic life as a wife and mother and that the practice of science risked driving them away.

During the 1890s, feminism was everywhere: numerous articles about feminism and women's rights were published in the daily press and in popular and specialised journals (Offen, 2018). In

\footnotetext{
${ }^{42}$ According to the first volume of the Bulletin of the Saint-Simon circle, the purpose of this foundation, created in 1883, was to bring together men who "have the cult of science and the mind" ("ont le culte de la science et des choses de l'esprit") by choosing history as"common ground" ("terrain commun") and thus to set up a "vast association inspired by the love of science and homeland" ("vaste association inspirée par l'amour de la science et de la patrie"). This positioning and the reference to Saint-Simon suggest, among other things, a position favorable to sex equality (in the sense that this may take in the 1880s). It should be noted that scientists like Paul Bert, an actor in the reforms for girls' education, were among them. The subject of Rebière's conference seems perfectly adapted to his audience.

43 "[...] moins légères que la marquise du Châtelet et moins tourmentées que Sophie Kowlevski”, "[...] les savantes, même les plus heureuses, ont ignoré le vrai bonheur."

44 "Une femme qui étudie les mathématiques est-elle forcément une mauvaise ménagère ? Non pas. La plupart des savantes dont nous avons parlé furent des épouses accomplies, d'excellentes mères de famille et celles qui les suivront dans la carrière des sciences auront, nous l'espérons bien, leurs vertus domestiques, avec leur mérite scientifique."
} 
1897 and 1898, the term "feminism" was contentious for several authors reviewing (Rebière, 1897): authors used Germain among other women to prove their point. ${ }^{45}$ In his review, Jacques Boyer (1869-?) announced his goal: "Since everything is feminism, the moment seems favorable to sketch in broad strokes this little-known part of its history." ${ }^{46}$ He then used (Rebière, 1897) to conclude :

$[\ldots]$ we met few women initiators [...] Now, to establish these findings, we rely only on the experience of centuries [without using contemporary medical research] [...] That, by the way, could not be due to a lack of education, but to [the] emotional nature [of the woman], to her sometimes quick but rarely deep mind that does not seem to predispose women to play an important role in science. (Boyer, 1898) ${ }^{47}$

Still in 1897 and 1898, a series of six articles entitled Les Femmes dans la science was published in the Christian feminist journal La Femme by the French feminist Marie Abbadie d'Arrast (18371913), ${ }^{48}$ (d'Abbadie d'Arrast, 1897-1898). She summed up several biographies of (Rebière, 1897) by noticing that Rebière did not position himself in relation to the various comments about women reported in his book (d'Abbadie d'Arrast, 1897-1898, vol. 20, n 5, p. 35). She also supplemented this with other examples, including Charlotte Angas-Scott, who belonged to the "United States School of Women's Science", ${ }^{49}$ and argued for sex equality in the sciences.

Another example of Rebière's reader is the mathematician d'Ocagne who wrote several historical summary articles, especially on calculation and calculating machines. ${ }^{50}$ In a conference entitled Les Femmes dans la science held on November 30, 1908 at the Université des Annales in Paris, a institution of higher education for young girls. Like Rebière, d'Ocagne listed short biographies of scientific women and some quotations on women in science. However, he introduced his text with two questions: "Are women, in general, as talented as men for the study of sciences, and if so, is it desirable that they take care of the study of sciences and in which way ?" ${ }^{11}$ He noticed that among women in science, the majority were women mathematicians. He gave several reasons to justify this fact: mathematics did not require "any material work" (d'Ocagne, 1909, p. 81); ${ }^{52}$ mathematics relied first on a form of divination, of intuition before the phases of rigorous reasoning; as such, could be thought of in analogy with poetry or music. Referring to Henri Poincaré (1854-1912), d'Ocagne also stated that mathematicians needed sensitivity to understand mathematical beauty. In the background, mathematics relied, among other things, on qualities that were most often given to women. From the testimonies of mathematics teachers who taught women - Felix Klein (1849-1925) in Göttingen and Carl Vogt (1817-1895) in Geneva - and continuing his analogy with music, d'Ocagne concluded that even if there were some outstanding women like Kovalevskaya, it seemed that most women were able to understand but not to invent mathematics. D'Ocagne then answered his second question: while it may be useful to encourage the few women with special skills for science, the science education for most women

\footnotetext{
${ }^{45}$ See for example Le Temps (June, 5) and (Boyer, 1898, p. 600).

46 "Puisque tout est au féminisme, le moment parait favorable pour esquisser à grands traits cette partie peu connue de son histoire."

47 “[...] nous avons rencontré peu d'initiatrices [...] Or, pour établir ces constatations, nous nous basons uniquement sur l'expérience des siècles [sans utiliser les recherches médicales contemporaines] [...] Cela, du reste, ne saurait tenir à un défaut de l'éducation mais à [la] nature émotive [de la femme], à son esprit vif quelquefois mais rarement profond qui ne semblent nullement prédisposer la femme à jouer un rôle important dans la science."

${ }^{48}$ A few years later, she chaired the Legislation section in the Conseil national des femmes françaises, created in 1901, and encouraged international collaborations on issues on women(Offen, 2018).

49 “l'École scientifique féminine des États-Unis"(d'Abbadie d'Arrast, 1897-1898, vol. 20, n 5, p. 37). Being part of the faculty members in Bryn Mawr college since its creation in 1885, Angas Scott played a central role in the implementation of mathematics programs in this institution of education and research reserved for women (Parshall, 2015).

${ }^{50}$ Maurice d'Ocagne is known for his work on graphical calculus: see Dominique Tournès work.

51 "les femmes sont-elles, en général, aussi douées que les hommes pour l'étude des sciences, et, dans ce cas, est-il souhaitable qu'elles s'en occupent et dans quelle mesure ?”(d'Ocagne, 1909, p. 64)

52 "Aucune besogne matérielle”.
} 
should remain general and superficial. A substantial science education would divert women from their family duties. On October 24, 1925, on the occasion of the public meeting of the Institut de France, d'Ocagne held another conference about women in mathematics, Quelques figures de mathématiciennes. If he noticed that the number of female scientific had become important, the point was similar. The general conclusion he uttered after Kovalevskaya's end-of-life narrative was even more pessimistic: "This lamentable epilogue of such a prestigious story seems well done to illustrate Madame de Stael's disillusioned word about the glory that, often, 'could only be for a woman the bright mourning of happiness"'(d'Ocagne, 1925). ${ }^{53}$

From these first references, the main points of debate concerning women in mathematics (and in science more generally) arise: appropriate level and nature of education for women; compatibility of the practice of mathematics or science with happiness and the domestic life, then considered natural and indispensable for women; compatibility of the (natural or socially constructed) qualities of women with the practice of mathematics. Germain was part of the list of women mathematicians presented and used by some authors to develop certain arguments and by others to develop opposing arguments. Subsequently, we see how specific characteristics of Germain's life and work were mobilised to fuel comments about women in mathematics in writings focused on the question of women's education and social sciences publications.

\section{IV.3 Which Education for Women ? Germain as an Argument to Develop or Restrain (Scien- tific) Teaching For Girls}

Throughout the nineteenth century, whether for boys and then for girls, education was not a route to social elevation in France: primary education was dedicated to the working class and separated from secondary education, defined to educate the bourgeoisie. Thus, for girls, both forms of teaching had to have very distinct objectives: manual labor and skills to work in the factory for the working classes; arts and skills to become a good mother and a good wife for girls from the bourgeoisie. The majority of the debates concerned the teaching of girls from the bourgeoisie and in this context, education of girls was gradually considered as an issue of society: wives, mothers, educators, and women were fundamental for the regeneration or, on the contrary, degeneration of the nation (Françoise, 1979). In the early 1830s and in the wake of the Guizot Law on primary education for boys, there was a progressive development of pedagogical and moral literature on the education of girls.

\section{IV.3.1 Germain as a Model of Vocation and Perseverance in Education and Morale Literature}

In a biography published after the death of Germain, Libri recalled in great detail the childhood obstacles that Germain had to overcome to train in mathematics. This trait of her character was included in books of morality and education for schools, families and children, when the development of youth literature was important, following the laws Guizot (1830s) and Falloux (1850) on primary education. Le Gymnase moral des jeunes personnes (Champagnac, 1837) included biographies of famous women. The goal of the writer Jean-Baptiste-Joseph Champagnac (1798-1858) was to provide models for young girls:

By offering our young [girl] readers a certain number of emulators capable of electrifying them by their examples, we wanted to open to them a kind of arena, where they could come to fight for merit and virtues with the models presented to them. ${ }^{54}$

A virtue was associated with each biography: for Germain, it was dedication ("vocation" in French), and her biography focused on her childhood and her perseverance to study mathematics despite her parents' hostility (Champagnac, 1837, pp. 52-68).

\footnotetext{
53 "Ce lamentable épilogue d’une si prestigieuse histoire semble bien fait pour illustrer le mot désabusé de Mme de Staël sur la gloire qui, bien souvent, 'ne saurait être pour une femme que le deuil éclatant du bonheur'”.

54 "En offrant à nos jeunes lectrices un certain nombre d'émules capables de les électriser par leurs exemples, nous avons voulu leur ouvrir une sorte d'arène, où elles pussent venir lutter de mérite et de vertus avec les modèles qui leur sont présentés." (Champagnac, 1837, p. 6)
} 
It is possible that Champagnac also wrote the Dictionnaire historique d'éducation published under the name of M. Delacroix ${ }^{55}$, an inspired version of the work of the same name by Jean-Jacques Filassier (1771). Germain was introduced there as one of the astonishing examples of dedication and sacrifice which can lead to the love of science (Delacroix, 1837-1838, p. 105), which is such an extraordinary vocation in a woman (Delacroix, 1837-1838, p. 108). ${ }^{56}$

Germain's childhood was also described and illustrated in one of the first journals for children, containing many illustrations, La semaine des enfants, created in 1857 (Barrau, 1860). The author of the article is likely Théodore-Henri Barrau (1794-1865), who was a pedagogue and promoter of primary education in France. Barrau also published the Livre de morale pratique (1872), where Germain appeared in the chapter entitled "Duties of man to himself": ${ }^{57}$ : "A woman, by her love of studying, managed to be among the first mathematicians of the nineteenth century". ${ }^{58}$

As we will see later, in comments by some authors on the ability of women to create mathematics, Germain's perseverance was not cited as a positive quality but more as proof of her lack of genius.

\section{IV.3.2 Contents and Goals of Higher Instruction for Women}

In the context of the debates on the education of women differentiated from that of men, Legouvé developed his work concerning women. For him, the failure of the French Revolution could be explained precisely because of the injustice that was then reserved for women. His principle of "equality in difference" postulated a feminine specificity which made it possible to propose a form of emancipation for women while preserving the ideal of the patriarchal family and the bourgeois-style social order in France (Offen, 1986). The theory of Legouvé was still central in the debates at the end of the Second Empire, when Minister Victor Duruy (1811-1894) tried to create a first public secondary education for girls. It was still fundamental in the Third Republic, during the implementation of the Camille Sée law and the many debates that followed the first feedback. Indeed, the form, content and purpose of this secondary education had to be decided. The place of science and mathematics in the curricula was minimal (Hulin, 2008): science was most often considered to wither young girls' minds, and mathematics, which was mainly used in preparatory classes for the grandes écoles, was particularly considered useless beyond the elementary arithmetic (Françoise, 1979).

In these debates, references to Germain were mobilised to argue for or against a high level of instruction for women or in a more specific way to discuss the possibility and the utility of a scientific or mathematical education for women. This last question was already ancient in the 1860s during the first reforms to create a public secondary education for women. In the fundamental Histoire morale des femmes, Legouvé wrote for example that women were incapable of generalisation, genius and invention in every intellectual and artistic field, including mathematics: "No mathematical discovery, no metaphysical theory is due to a woman.” (Legouvé, 1849, p. 372$)^{59}$

For Republicans, women's education was fundamental. In his speech on equality of education of April 1870, Minister Jules Ferry (1832-1893) already said: "Bishops know it well: the one who holds the woman, that one holds everything, first because he holds the child then because he holds the husband [...] That's why the church wants to keep the woman, and that's also why democracy has to take her away from the church".$^{60}$ At this time, many publication projects on teaching and pedagogy were born. This is for example the case of the Dictionnaire de pédagogie edited by the philosopher

\footnotetext{
${ }^{55}$ See La Littérature française contemporaine, 1827-1844, vol. 3, eds Ch. Louandre and F. Bourquelot, 1848, p. 296.

56 "exemples étonnants du dévouement et des sacrifices aux quels peut conduire l'amour des sciences", "une vocation si extraordinaire dans une femme".

57 "Devoirs de l'homme envers lui-même"

58 "Une femme, par son amour pour l'étude, parvint à se placer parmi les premiers mathématiciens du dixneuvième siècle". (Barrau, 1872, p. 73)

59 "Aucune découverte mathématique, aucune théorie métaphysique n’est due à une femme."

60 "Les évêques le savent bien : celui qui tient la femme, celui-là tient tout, d'abord parce qu'il tient l'enfant, ensuite parce qu'il tient le mari[... ]C'est pour cela que l'église veut retenir la femme, et c'est aussi pour cela qu'il faut que la démocratie la lui enlève".
} 
and Republican Ferdinand Buisson (1841-1932), on which many authors like Legouvé collaborated. Debates on education that took place during the revolutionary period were fundamental examples in this literature. For example, George Dumesnil (1855-1916), in his Pédagogie révolutionnaire (1883), analysed Condorcet's writings at length and referred to Germain to justify the mathematical skills of women. Moreover, with the establishment of a secular moral education program under the Third Republic, the essential role of women in the family continued to be central to pedagogical writings. Several moral works were written by women. Among these, Francinet by G. Bruno ${ }^{61}$ was a real bestseller for children aged 11 to 13 from its first edition in 1869 (Offen, 2018). In this book, the author insisted that a mother's influence was a central factor in a child's education. She nevertheless suggested possible mathematical capacities for girls when telling Germain's story through a teacher, Mr. Edmond. One of the three children who were listening, a girl, reacted:

Thank you, sir, said Aimée, for telling us this interesting story. I am very proud to know that there was a girl as intelligent and as learned. I did not think women were able to understand anything about mathematics. (Bruno, 1869, p. 505) ${ }^{62}$

Statistical surveys and teachers' testimonies multiplied in the 1880s, with the first French laws on public secondary education for young girls, the development of women's education in Europe and discussions about the model of American coeducation. More generally, with the general rise of statistics, increasing numbers of studies on the place of women in society were being conducted. On this point, the book led by the American journalist Théodore Stanton (1851-1925), The Woman Question in Europe is an emblematic example. It was published in 1884 from the results of an investigation launched by Stanton in 1878, following the first congress on women's rights organised in France by Léon Richer and Marion Deraisme. Education for girls played an important role in this book composed of seventeen chapters, one each for seventeen different countries (Offen, 2012). The naturalist Nicolas Joseph Joly (1812-1885), a professor at the Science faculty in Toulouse, referred in particular to Stanton in his article "Dans l'espèce humaine à égalité d'instruction les intelligences sont égales chez les deux sexes" ("In the human species with equal education the intelligences are equal in both sexes") (1885). Based on the principle of Legouvé, Joly thus defended the equality of intelligence (and not identity) between the two sexes, while defending the existence of mathematical abilities for women:

Like so many others Mr. Legouve at their head, I had for a long time shared the opinion of believing that women have no aptitude for the mathematical sciences; but I had to face the facts when I saw the sister of Mr. Theodore Stanton follow fruitfully the courses of transcendental mathematics of our eminent and regretted colleague Despeyrous. (Joly, 1885, p. 150) ${ }^{63}$

Joly also cited Kovalevskaya and Germain to support his remarks. Note also that two years later, Legouvé also returned to his statement on women and mathematics, after observing the performance of girls in this domain.

If Germain was regularly referenced to justify the usefulness of girls' education, sometimes even in science, her example could also serve as a contrary argument. Indeed, many authors argued that too much education for women could denature them or distort them from their natural familial functions. Feminists could rely on the existence of recognised women scientists to counter this view. Nevertheless, De Witt, quoted previously, relied on Germain to justify, on the contrary, the uselessness of a higher education:

\footnotetext{
${ }^{61}$ Under the pseudonym G. Bruno was actually hiding the wife of Alfred Fouillée (1838-1912), philosopher whose work included psychological studies.

62 "Je vous remercie bien, monsieur, dit Aimée, de nous avoir raconté cette intéressante histoire. Je suis toute fière de savoir qu'il y ait eu une jeune fille aussi intelligente et aussi savante. Je ne pensais pas que les femmes fussent capables de comprendre quelque chose aux mathématiques."

63 "Comme tant d'autres, M. Legouvé à leur tête, j'avais longtemps partagé l'opinion qui consiste à croire que les femmes n'ont aucune aptitude pour les sciences mathématiques ; mais j'ai dû me rendre à l'évidence quand j'ai vu la sœur de M. Théodore Stanton suivre avec fruit les cours de mathématiques transcendantes de notre éminent et regretté confrère Despeyrous.”
} 
[... ]Mlle. Sophie Germain had excited by her work the surprise and admiration of M. de Lagrange. But neither of these great [women] mathematicians [Germain and Sommerville] had received special and higher education. [...] The keys, often useless, were not forged beforehand for doors which they did not bother to open, as professors too often do not always remember. The purpose of women's education is to make women worthy of the name, natural, effective and useful companions of men to whom God has placed them. ${ }^{64}$

These debates, surveys and other studies were also regularly discussed in the daily or weekly press. This was for example the case of the journalist Henri de Parville, known for his writings on science and industry: ${ }^{65}$ he summed up several recent publications on women to discuss their abilities in science on the occasion of Klumpke's doctoral thesis, in an article published on December 20, 1893 in the Journal des débats politiques et littéraires (Parville, 1893).

As mentioned earlier, many writings on feminism were also published at the turn of the 20th century. The results of the surveys on women's education were also used in this context. This is for example the case of the article written by Marie-Thérèse de Solms-Blanc (1840-1907) under the pseudonym Thérèze Bentzon: it was published, in 1902 in the journal Le Carnet and was part of a series of texts entitled "Survey on Feminism". Bentzon had been collaborating since the early 1870s in the Revue des deux mondes. An expert in American literature, she traveled in the United States on behalf of the journal in the 1890s and was therefore well aware of the situation of women across the Atlantic (Offen, 2018, pp. 189-190). Thus, she reported the words of Bryn Mawr College President, Martha Carey Thomas (1857-1935): the proportion of women students was continually increasing and young women graduates, in addition to being able to find suitable work if needed, became very good mothers. According to Bentzon, the situation in Europe was of course different because there were fewer job opportunities for qualified female. Nevertheless, an educated woman was, according to her, a better mother, and the unmarried women could thus benefit from a "spiritual and moral maternity" which was equal to biological motherhood (Bentzon, 1902, p. 435). ${ }^{66}$ In addition, many women had previously demonstrated their literary or scientific excellence, with Germain and Kovalevskaya being cited for science. If Bentzon defended the feminine specificity, she also affirmed the importance for unmarried women at least to be able to exercise a profession and at pay equal to men. The position of another author, a few years later, was really different: Emma Angot (1850-?), in her article "A bit of feminism", published in Le Correspondant in 1909, affirmed that women were inferior to men in several fields and that even if some jobs could be adapted to women, it was useless, even dangerous, to add tension to the job market. Dangerous because it could further move women away from marriage. The aim of girls' education was therefore to develop their feminine qualities and not to inculcate in them a useless science. For Angot, Marie Curie was the dangerous example par excellence "because she turned many heads" (Angot, 1909, p. 956), ${ }^{67}$ and Sophie Germain did not provide proof of the usefulness of women in science. But the role of women must above all be moral:

And when intellectual progress is assured, will there be moral gain? No, certainly. Then there is nothing done. France does not decline for lack of knowledge, it collapses for lack of principles; and if women try to awaken national self-esteem and elevate private dignity, it is not the card of solidarity or even the degree of license that will help them. (Angot, 1909, p. 968)

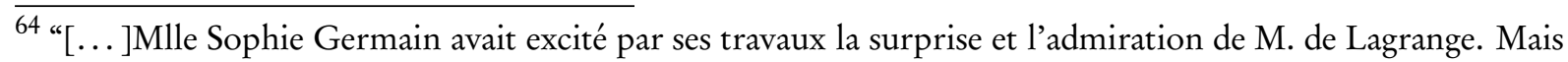
ni l'une ni l'autre de ces grandes mathématiciennes [Germain et Sommerville] n'avait reçu un enseignement spécial et supérieur. [...] On ne leur avait pas forgé d'avance les clefs, souvent inutiles, pour des portes qu'elles ne se souciaient pas d'ouvrir, comme le font actuellement trop souvent les professeurs, qui ne se rappellent pas toujours que le but de l'éducation féminine est de faire des femmes dignes de ce nom, compagnes naturelles, efficaces et utiles des hommes auprès desquels Dieu les a placées [... ]" (Witt, 1888, p. 394)

${ }^{65}$ See his obituary in the Journal des débats politiques et littéraires of July 12, 1909.

66 "maternité spirituelle et morale qui vaut bien l'autre".

67 "car il a tourné bien des têtes".

68 "Et quand le progrès intellectuel serait assuré, en sortira-t-il un gain moral ? Non, certainement. Alors il n'y a rien de fait. La France ne décline pas faute de savoir, elle s'affaisse faute de principes; et si les femmes essayent de
} 
These remarks by Angot referred to a shared fear at the beginning of the twentieth century of national degeneration and depopulation. Like the prospect of unmarried women, women's work was considered by anti-feminists (and some feminist currents) as a threat to motherhood and the national birth rate (Bologne, 2004; Offen, 2012). To the arguments of doctors affirming maternity as natural thus followed the idea of maternity as a patriotic duty (Knibiehler, 1976).

\section{IV.4 The Question of Women through the New Social Sciences: Germain as a (counter-)example}

Since the seventeenth century, reason and natural law were considered by scholars and philosophers as fundamental to any enlightened society. Natural and biological laws were thus used to deduce social laws (Offen, 1986, p. 460). The use of science to study the "nature of women" and in particular to justify their inadequacy to all intellectual activity was more and more frequent from the second half of the eighteenth century. A new model was also gradually imposed: that of the incommensurability of the sexes. It was well-illustrated by the words of Rousseau: "in what they have in common, they are equal; in that they are different, they are not comparable". ${ }^{69}$ In the 1750 s, several successful books were devoted to the study of the "nature of women" ((Roussel, 1775) for example). With this incommensurable sex model, there were two bodies, totally infused with the masculine or feminine (Laqueur, 1992). From the second half of the eighteenth century, demonstrations of the natural difference existing between women and men were made from the consideration of their skeletons: if this difference was observable in bones, which did not have a procreative function, it could prove that there was a difference beyond just genitalia between men and women. Using skeletons to justify natural differences between man and woman was far from innocuous. The skeleton was then thought of as an ideal object of study for the analysis of the body. In addition, the advent of paleontology at the turn of the nineteenth century, and with it the validation of the importance of fossil bones, contributed to enhancing the study of skeletons for the study of the human. At the sametime, starting in the nineteenth century, measurements were made on different parts of the skeleton, and especially the skull to measure intelligence and its evolution within the human species. This idea that the mind and intelligence could be based on the material study of the brain and nervous system was developed throughout the nineteenth century (Peyre and Wiels, 1995).

It was in this context that phrenology was developed by Franz-Josef Gall (1758- 1828), who postulated relationships between human faculties and the shape of the skull, considered as formative for the brain. If phrenology was criticised, many treatises were dedicated to this science in the nineteenth century. Phrenological work was based on an important iconography, consisting of portraits of ancient men, skulls or preserved casts and studies of living people. In several publications, phrenologists base their remarks on a collection of portraits. Many artists also practiced phrenology (Baridon, 2003). From the 1840s at least, the skull of Germain was regularly cited to illustrate some intellectual faculties such as "habitativity" and "concentrativity". ${ }^{70}$ For example, the French painter Jean Hippolyte Bruyères (1801-1855), son-in-law to one of Gall's collaborators, published in 1847 a book entitled La Phrénologie. Le geste et la physionomie démontrés par 120 portraits, sujets et compositions gravés sur acier, in which some of Germain's intellectual and behavioral faculties are analysed from observations of her skull:

Plate $\mathrm{n}^{\circ} 7$ contains an example of great development of the organ attributed to the penchant of the habitativity: it is a bust, molded on nature after the death, of miss Sophie Germain, known by her talent in mathematics: she was sedentary and homeless, and for a great number of years she did not leave her room: her occupations helped to give strength to her home instinct $[\ldots]$ She was original and aimed at singularity: self-esteem and firmness are very pronounced on her head [...] the organ of calculation is very marked. In the hypothesis of an organ of concentrativity, the considerable development of the region of habitativity on this head can make it possible to admit that the two organs exist together to a

réveiller l'amour-propre national et de relever la dignité privée, ce n'est point le brevet de solidarité ou même le diplôme de licence qui les y aidera."

69 "en ce qu'ils ont de commun, ils sont égaux ; en ce qu'ils ont de différent, ils ne sont pas comparables."

${ }^{70}$ Germain was also take as an example in (Cubí i Soler, 1858; Rengade, 1881). 
high degree. And, in fact, Mademoiselle Germain was exclusively engaged in her calculating work with a great strength of concentration of mind (Bruyères, 1847, pp. 46-47)

It is easy to see here direct links between this description and some biographical aspects of Germain: for example, firmness is described later in the book as a characteristic of "obstinate and stubborn children" (Bruyères, 1847, p. 131) ${ }^{72}$ which probably referred to her childhood. Bruyères also distinguished computational abilities with more general mathematical faculties, citing in particular prodigious calculators that showed a mathematical incompetence. This opposition between computer and mathematician would be a regular argument to minimise women's achievements in mathematics as we will see below.

In the 1860s, the question of women returned to the scene and was debated particularly by actors of the new humanities such as sociology, anthropology, and psychology. Many authors defended the inferiority of women through scholarly publications. They developed scientific studies on the sizes of skulls and brains, and using Darwin's and Spencers' theories of evolution. Exceptions like Germain were generally justified by their lack of femininity. Thus, the philosopher Etienne Vacherot (1809-1897), Republican and defender of democracy against the imperial regime and religion under the Second Empire, wrote in a chapter on the psychological method that scientific thought was a virile thought. Women who had distinguished themselves in mathematics, like Germain, "who calculated like a geometer and thought like a metaphysician", had "lost the spirit" of the woman and "acquired in exchange a virile spirit". (Vacherot, 1869, p. 258) ${ }^{73}$ Proponents of women generally responded with an ancient argument, but used more and more frequently: female inferiority was socially constructed (Offen, 2012; 2018). These debates were obviously not unrelated to those on women's education mentioned above. In 1879, the doctor and anthropologist Gustave Le Bon (18311941) used the measurement of skulls to affirm that the inferiority of all women, some social classes and certain races was accentuated with the progress of civilisation (Knibiehler, 1976). He concluded that girls' education had to be very limited, because it could be dangerous for women and therefore to family and society more generally. Several feminist Republicans opposed such 'scientific' discourses by regularly using the results of the first surveys of women's education in the United States and France. Some also answered with scientific arguments: the anthropologist Léonce Manouvrier (1850-1927) published an article in the Revue scientifique in 1882 in which, in response to the theory of Le Bon, he showed that the size of the brain in men and women was proportional to body mass. Nevertheless, Manouvrier did not deduce an absolute equality of the physical and intellectual faculties of men and women: "the muscular superiority of males and the gestational requirements of females necessarily resulted in a sexual division of labor that accentuated secondary sexual differences." (Offen, 2018, p. 82) These scientific-medical arguments were regularly reproduced in the press or used in pedagogical debates. Professor Joly, in his article above mentioned on gender equality, exposed his fears concerning this type of speech: "But, even today, unkind philosophers and physiologists or relying on inaccurate data, pose, as an axiom, the intellectual inferiority of the woman in parallel with the male sex." (Joly, 1885, p. 131)

\footnotetext{
71 "La planche $\mathrm{n}^{\circ} 7$ contient un exemple d'un grand développement de l'organe attribué au penchant de l'habitativité : c'est un buste, moulé sur nature après la mort, de mademoiselle Sophie Germain, connue par son talent en mathématiques : elle était sédentaire et casanière, et, pendant un grand nombre d'années, elle n’a point quitté sa chambre : ses occupations contribuaient à donner de la force à son instinct casanier [...] Elle était original et visait à la singularité : l'estime de soi et la fermeté sont très prononcées sur sa tête [...]l'organe du calcul est très marqué. Dans l'hypothèse d'un organe de la concentrativité, le développement considérable de la région de l'habitativité sur cette tête peut faire admettre que les deux organes existent ensemble à un haut degré. Et, en effet, mademoiselle Germain était exclusivement livrée à ses travaux de calcul avec une grande force de concentration d'esprit.

72 "enfants opiniâtres et têtus".

73 "qui calculait comme un géomètre et pensait comme un métaphysicien”, "perdu l'esprit", "acquis en échange un esprit viril”.
} 
Those debates were also taken in hand in socialist and feminist literature by authors who vividly criticised so-called scientific arguments showing women's intellectual inferiority in feminist journal such as Le Droit des femmes or socialist périodicals like La Revne socialiste. In the latter, the feminist and socialist Léonie Rouzade (1839-1916) published a text entitled "Les Femmes devant la démocratie" to defend, against anthropological and other scientific arguments, the idea that women's inferiority lay in social and cultural causes and that education should resolve the problem. She argued for equal rights and general access to work in order to assure emancipation and independence for women. She explicitly aligned herself with socialist thought, using the socialist formula "à travail égal, salaire égal" ("Equal pay for equal work") and promoting education for all people, men and women (Rouzade, 1887). In the same order of ideas, the socialist Johannes Sagnol (1863-1948) published in the same periodical "L'égalité des sexes", where he also defended physical sex equality - because men's general physical superiority was balanced by women's superior functions in reproduction - and intellectual sex equality. According to him, every question regarding nature or society was analysed by science but as science was not precise enough, the objectivity of scientific claims was more than questionable (Sagnol, 1889 , p. 685). In his article, Sagnol proposed a socialist advocacy in favour of women rights. Indeed, according to Sagnol, despite the limitations that had always been imposed on women by men, especially to join the liberal professions, women regularly showed their intellectual superiority, like Germain "who, at age 14 was the strongest mathematician of her time" (Sagnol, 1889, p. 694) ${ }^{74}$ For Sagnol, the physical, intellectual and moral equality of men and woman should induce social equality: "Now, since [the woman] is equal to [the man], she is entitled like him, with the same independence and the same social benefits." (Sagnol, 1889, p. 697) ${ }^{75}$ For Rouzade and Sagnol, equality did not mean identity: they both agree on complementarity between men and women, the former having in particular the physical strength and the latter, the fertility. But they both advocated that physical strength lost its importance in a more and more mechanised society and that in industrialised civilisations, women and men could perform equally in numerous jobs. They also promoted instruction for both men and women, from all social classes, because the lack of instruction, in particular scientific, was the reason for the supposed intellectual inferiority of women. While both Rouzade and Sagnol placed the family as a central element of society, they also advocated a major shift in family structure, in which women would be more independent: with this model, intellectual women should not be regarded as dangerous, on the contrary.

By the end of the 1880s and the 1890s, demands for women's rights were growing, as more and more women entered secondary or higher education and had a profession. Feminist publications were still developing; two international congresses for women's rights were organised in 1889. The question of women was still debated with scientific arguments: the knowledge war was revived by anti-feminist writers around the issue of women's mental capacity (Offen, 2012; 2018). Books that quickly became best-sellers were published. The biologists Patrick Geddes (1854-1932) and John Arthur Thomson (1861-1933) thus published in 1889 The Evolution of Sex, based on Darwin's evolutionary theory; they argued that intellectual and affective differences between the sexes were essential (Offen, 2012). Shortly after, the works of Cesare Lombroso (1835-1909) and his son-in-law historian Guglielmo Ferrero (1871-1942) were at the heart of the debate. Lombroso, considered the founder of criminal anthropology, had already published L'uomo delinquente in 1876. Merging statistics, anthropology, and evolutionary theory, he argued that delinquency was a natural disposition and that criminals were beings that had not completed their evolution (Kaluszynski, 1989). In 1893, La Dona delinquente, the prostituta e la donna normal by Lombroso and Ferrero appeared. In Part I, devoted to the "normal woman", Chapter IX dealt with intelligence. That of the woman was then characterised by "the absence of any creative power": even if illustrious women had existed, like Germain in mathematics, they were much less frequent than men and remained far from "the power of male geniuses" (Lombroso and Ferrero, 1893, p. 166). Lombroso and Ferrero criticised Sagnol's thesis: for them, the inferiority of

\footnotetext{
74 “qui, à 14 ans était la plus forte mathématicienne de son temps".

75 “Or, puisque [la femme] est l'égale de [l'homme], elle a droit comme lui, à la même indépendance et aux mêmes avantages sociaux."
} 
women could not be explained by "social conditions" (Lombroso and Ferrero, 1893, p. 166) since even when they received an education similar to that of men (as in the French aristocracy of the eighteenth century), they showed no trace of genius. They said that women with higher intellectual abilities were actually male. Finally, if they were incapable of creativity or synthesis, women knew how to assimilate and reproduce, which explained the good or even better success of girls in studies (Lombroso and Ferrero, 1893, p. 172). This book, strongly criticised, was nevertheless a great success, and was partially translated into English in 1895, and completely in French in 1896.

Many French scientists, like Manouvrier, strongly opposed Lombroso's theories. Between 1896 and 1914, several scientists gathered around Alexandre Lacassagne (1843-1924) to develop criminal anthropology while denouncing the overly simplistic position of Lombroso and his Italian colleagues on the born criminal: for them, the social milieu also played a fundamental role in revealing delinquency (Kaluszynski, 1989). They admitted, however, a natural basis of crime. Similarly, for Lacassagne, there were natural differences between the sexes. Thus, Lacassagne wrote in the section devoted to the sexes of his Précis de médecine légale (1906):

The real difference is in brain function. In women, feelings predominate, in men intelli- gence. Women are occipitals, men are frontal. Hence their inability in science. Except Sophie Germain and Sophie Kowalewsky, not one woman was superior in mathematics. The grand generalisations of physics and biology are not within their reach. (Lacassagne, 1906, p. 130) ${ }^{76}$

Those scientists, often close to Republican circles, applied the famous principle of "equality in difference". Alfred Fouillée (1838-1912), in psychology, published in the Revue des denx mondes in 1893 an article entitled "La Psychologie des sexes et ses fondements physiologiques", then reproduced in a more general work in 1895 (Fouillée, 1895). He began by recalling the importance of biological considerations in educating psychological, moral and social relations between the sexes. He objected, however, to overly simplistic methods, such as the weighing of skulls, and based his argument on recent discoveries concerning reproduction. In his chapter on women and men's intelligence, Fouillée positioned himself against Le Bon and Lombroso, relying in particular on the writings of Manouvrier to affirm the equality of brain development in both sexes. Nevertheless, he defended the idea of the sexual specificities of intellect and supported the fact that "the functions which aim at the propagation and the nutrition of the species are in antagonism with too much expenditure of the brain" (Fouillee, 1893, p. 415) ${ }^{77}$ : with Fouillée, the man remained more adapted to generalisation, whereas the woman had intuition and sagacity for particular facts. Against Le Bon, who had postulated that women were incapable of scientific reasoning, Fouillée gave examples of women who showed exceptional scientific skills, such as Germain. But these women still had to remain exceptions: "A force and an expenditure of intelligence which, if they were general among the women of a society, would lead to the disappearance of this very society, must be considered as an attack on the natural functions of sex." (Fouillée, 1893, pp. 420-421 $)^{78}$ Hence a need to offer an education to a woman to eventually learn "the professions that are related to the capabilities and dignity of her sex" but especially prepare "for domestic life, her role as a wife, as a mother, and educator". (Fouillée, 1893, p. 425) 79

Theories like that of Fouillee met their opponents. For example, the sociologist Jacques Lourbet, in La Femme devant la science contemporaine (1896), explicitly attacked misogynist authors like Fouillée

\footnotetext{
76 "La véritable différence se trouve dans les fonctions cérébrales. Chez la femme prédominent les sentiments, chez les hommes l'intelligence. Ce sont des occipitales, les hommes sont des frontaux. De là leur inaptitude aux sciences. Sauf Sophie Germain et Sophie Kowalewsky, pas une femme n'a été supérieure en mathématique. Les grandes généralisations de la physique, de la biologie ne sont pas à leur portée".

77 "les fonctions qui ont pour but la propagation et la nutrition de l'espèce sont en antagonisme avec une trop forte dépense du cerveau."

78 "Une force et une dépense d'intelligence qui, si elles étaient générales parmi les femmes d'une société, amèneraient la disparition de cette société même, doivent être considérées comme une atteinte aux fonctions naturelles du sexe."

79 “aux professions qui sont en rapport avec les capacités et avec la dignité de son sexe”, “à la vie domestique, à son rôle d'épouse, de mère et d'éducatrice."
} 
and their problematic use of science: "Science! What a beautiful passport today for paradoxes!" (Lourbet, 1896, p. 67) On the contrary, he insisted on "the influence of the environment on the woman" (Lourbet, 1896, p. 75), taking away from Fouillée's arguments about insects: "We see that in these insects a certain environment awaits the larvae and makes, according to the case, workers or queens; in this way the sovereign power of the milieu is clearly affirmed" (Lourbet, 1896, p. 82 ).$^{80}$ Lourbet thus considered it remarkable that, in the conditions of subordination in which women had been locked up for centuries, so many women (including Germain in mathematics) "have been illustrious in the sciences, the humanities, the arts, and even in war, and who [have] become supreme leaders of the people!" (Lourbet, 1896, p. 85) ${ }^{81}$

Another author who used Legouve's principle, "equality in difference", was the philosopher Henri Marion (1846-1896). A Republican reformer of the Third Republic, Marion was the author of several books and pedagogical articles. Elected to the Council of Public Instruction in 1878, he participated in the organisation of secondary education for girls. He taught his course on the "science of education" at the Sorbonne from 1883 to 1896, a course published in two volumes posthumously. In the first volume, Psychologie de la femme (1900), Marion proposed a science of psychology-based education to determine the "nature of women" (Mosconi, 2012). Marion thus proposed an analysis of the specificities of the intelligence of the woman: "The woman is as intelligent as the man, she is so only otherwise. Let us look more closely, faculty by faculty, at what are the characteristic differences"(Marion, 1900, p. 197), namely an ability to store rather than reason personally, an "omnipresent" imagination but lacking "power and fertility" (Marion, 1900, p. 205), a "futile curiosity" rather than "broad, selfless, truly intellectual." (Marion, 1900, p. 208) According to Marion, the woman could nevertheless excel in the mathematical sciences, as Kovalevskaya and Germain for example: "The proof is made, it seems to me, that the woman can be a great mathematician and that there is no incompatibility radical between her natural gifts and the highest scientific culture, at least in the order of the exact sciences" (Marion, 1900 , p. 212). On the other hand, according to Marion, women lacked the capacity for abstraction and generalisation in the natural sciences. In any case, learned men and philosophers were sufficient to advance knowledge: it was much more useful for women to perform their own functions: "maternity", "softening social life" and the preservation of traditions and morals (Marion, 1900, p. 220).

At the turn of the twentieth century, the neurologist Paul Julius Möbius (1853-1907) published a book on the foundations of mathematics (1900) and applied his neurological theory to express his opinion on the abilities of women in this field. Taking up the idea that women had no capacity for abstraction or creativity, he de- fined women mathematicians as the result of a process of degeneration. This idea joined Lombroso's theories and more generally the literature on the intermediate sex types of the time, which resulted from abnormalities during the development of indi- viduals (Rowold, 2001). His argument was also based on social and historical facts. On the one hand, he noted that the number of women with mathematical skills was extremely low (he announced one woman in a million...) and that a woman practicing mathematics was unnatural. On the other hand, according to him, the women who left their names in the history of mathematics did not introduce anything innovative: ${ }^{82}$

It can be said that a female mathematician is unnatural; it is in a certain sense a hermaphrodite [...] Sophie Germain has the appearance of a man; Kovalevsky proves that a woman can hardly possess genius and health [...] It is an exaggeration to speak of mathematical genius of the woman; none has found anything essential, none has devised new methods. They were good students, nothing more. [...] The most original was Germain. ${ }^{83}$

\footnotetext{
80 "On voit par là que chez ces insectes un certain milieu attend les larves et en fait, selon le cas, des ouvrières ou des reines ; ainsi s'affirme d'une manière éclatante la puissance souveraine du milieu."

81 “qui se sont illustrées dans la sciences, les lettres, les arts, la guerre même, ou qui sont devenues les chefs suprêmes des peuples !”

${ }^{82}$ On that subject, he also criticised vividely Rebière's too wide acceptation of the notion of "women in the science".

83 "Man kann also sagen, daß ein mathematisches Weib wider die Natur sei, in gewissen Sinne eine Zwitter [...] Von den Mathematikerinnen sieht besonders Sophie Germain männlich auss. Die Kowalewsky zeigt, daß
} 
Germain was described by Möbius as original precisely because she worked alone her whole life; she did not have any father, brother or husband to assist her.

Möbius's writings were taken up and discussed by many authors. Thus, the controversial Otto Weininger (1880-1903), relied notably on Möbius (the latter accused him of plagiarism) in his book Geschlecht und Charakter. Eine prinzipielle Untersuchung (1903), which also became a huge success. $\mathrm{He}$ used his principle of intermediate sex forms to study the capacity of women to be independent. To become the internal equal of the man, "to attain his intellectual and moral freedom, his interests and creative power" (Weininger, 1903, p. 58), the woman had to develop a degree of masculinity. Even in this case, women remained intellectually far inferior to men: Germain was one of those women who were recognised only because of gender and were not as intelligent as men of the fifth or sixth rank of genius. This intellectual inferiority of women was due to feminine psychology:

No woman has any real interest in science, even though she may successfully pretend that she has, both to herself and to many good men who are bad psychologists. We can be certain that behind every woman who has been able to claim an independent scientific achievement that was not totally insignificant (Sophie Germain, Mary Sommerville, etc.) there was always a man, to whom she was trying to get closer in that way. (Weininger, 1903 , p. 168$)^{84}$

Some extracts of Möbius' text were also translated into French by the Italian mathematican and historian of mathematics Gino Loria (1862-1954) and concluded his article "Les femmes mathématiciennes" published in 1903 in La Revue scientifique. Loria's purpose was to answer the following question:

Do the notions of feminine psychology that we possess lead us to consider as probable, or even as simply possible, that the woman is destined to give to the future, to science, contributions comparable to those that will be transmitted to the most distant the glorious names of Pythagoras and Newton, Archimedes and Leibniz, Descartes and Lagrange? (Loria, 1903)

Loria announced that he was going to use statistics, "this cold and implacable investigator of the principles that govern human actions" 86 , that is to say the historical data he had about women in mathematics. The question was fundamental to him because its answer should be able to guide political and individual decisions about the adequacy of women for mathematics. According to him, women could advantageously do complex calculations, especially in astronomy, thanks to their "patience" and their "tact" (Loria, 1903). But

There is a profound difference between the intellectual work of the astronomer who observes stars and performs mathematical calculations by applying now classical formulas, and the original work of one who does mathematics and researches the properties of figures. ${ }^{87}$

Gesundheit und hervorragendes Talent beim Weibe schwer zusammenbesteben [... Es ist eine Uebertreibung, wenn vom mathem. Genie bei Weibern gesprochen wird. Niemand wird bezweifeln, daß die Mathematik sich ebenso günftig entwickelt haben würde, wenn die aufgezählten weiblichen Mathematiker nicht gelebt hätten. Keine hat etwas Wefenttliches geleiftet, neue Methoden erdacht. Sie waren gute Shülerinnen, nicht mehr [... ] Um originellften scheint die Germain gewesen zu sein.” (Möbius, 1900, pp. 85-86).

84 "Kein Weib hat wirkliches Interesse für die Wissenschaft, sie mag es sich selbst und noch so vielen braven Männern, aber schlechten Psychologen, vorlügen. Man kann sicher sein, daß, wo immer eine Frau irgend etwas nicht ganz Unerhebliches in wissenschaftlichen Dingen selbständig geleistet hat (Sophie Germain, Marie Sommerville etc.), dahinter stets ein Mann sicher verbigt, dem sie auf diese Weise näher zu kommen trachtete[...]"

85 "les notions de psychologie féminine que nous possédons conduisent-elles à considérer comme probable, ou même comme simplement possible, que la femme soit destinée à donner à l'avenir, à la science, des contributions comparables à celles que transmettront à la postérité la plus éloignée les noms glorieux de Pythagore et Newton, d'Archimède et Leibniz, de Descartes et Lagrange ?"

86 "cette froide et inmplacable investigatrice des principes qui gouvernent les actions humaines"

87 "il y a différence profonde entre le travail intellectuel de l'astronome qui observe des astres et effectue des calculs mathématiques en appliquant des formules désormais classiques, et le travail original, de celui qui fait des mathématiques et recherche les propriétés des figures." (Loria, 1904) 
What about women who actually did mathematics? He used biographical elements of Germain's life in order to show that her accomplishments were not so original but laborious:

Her anonymous correspondence with Gauss, the "princeps mathematicorum" of the Germans, places her at the head of scholars who appreciated the inestimable value of new methods and became familiar with the handling of these delicate and powerful methods by which the immortal analyst gave a new and solid foundation to higher arithmetic. The manner in which Sophie Germain treated a question put to the competition - on the proposition of Napoleon I. - by the Institut de France, gave proof of an extraordinary perseverance, of a singular tenacity, rather than an exceptional analytical skill. (Loria, 1903) 88

He concluded by recalling the words of Möbius, which confirmed his theory. This publication was followed by exchanges with Josephine Joteyko (1866-1928) in this same journal (Joteyko, 1904; Loria, 1904). She was a Polish psychologist who studied child development to build a modern and rational pedagogy (Wils, 2005). She first studied in Geneva and obtained her doctoral thesis in Paris in 1896. In her answer to Loria, Joteyko highlighted contradictions in Loria's arguments and insisted on the importance of the debate, in relation with the one about the possibility for women to enter universities.

Finally, note that these debates were reproduced, recalled and discussed in a wide variety of publications. Thus, Joteyko's answer was also published in the journal La Femme. Loria's words were partially reproduced in the journal La France médicale in 1903 and Möbius' ideas were evoked in the Journal de la jeunesse in 1905. The lack of feminity of women mathematicians, such as Germain, was also used in some articles of the daily press, as in Le Petit parisien (January 6, 1906):

Another forgotten, Sophie Germain, whose name disappears between these two dates: 1776- 1831, on her gravestone, has fixed the attention of our city officials, who have recently dedicated to her one of their schools. She was the least woman of women: she was thirteen when she became passionate about mathematics, she studied alone, limiting herself to submit from time to time by letters her observations to scholars who took her for a student of the École polytechnique. An academic award, won by her about a horribly abstruse question, forced her to say who she was. As a true mathematician, she did not seek any other title than that of Miss X... ${ }^{89}$

\section{Conclusion}

As a woman, Germain had to be a self-taught mathematician because she had no access to mathematical instruction and more generally to institutions. She also had to overcome prejudices about the inadequacy of women for mathematics. Moreover, it was difficult for her, as a single woman, to build relationships with male mathematicians. Nevertheless, the political and scholarly proximity of her family to several social circles certainly played a role in her passion for mathematics and her possibilities for meeting scholars. Furthermore, as a woman practicing mathematics, and therefore as an

\footnotetext{
88 "Sa correspondance anonyme avec Gauss, le "princeps mathematicorum" des Allemands, la place à la tête des savants qui surent apprécier l'inestimable valeur des méthodes nouvelles et se familiariser avec le maniement de ces méthodes délicates et puissantes grâce auxquelles l'immortel analyste donna une base nouvelle et solide à l'arithmétique supérieure. La façon dont Sophie Germain traita une question mise au concours - sur la proposition de Napoléon 1er - par l'Institut de France, donna la preuve d'une persévérance extraordinaire, d'une singulière ténacité, plutôt que d'une habileté analytique exceptionnelle."

89 "Une autre oubliée, Sophie Germain, dont le nom s'efface entre ces deux dates : 1776-1831, sur sa pierre tombale, a fixé l'attention de nos édiles, qui lui ont récemment dédié une de leurs écoles. Celle-ci fut bien la moins femme des femmes : elle avait treize ans lorsqu'elle se prit de passion pour les mathématiques, qu'elle étudia seule, se bornant à soumettre de temps en temps par lettres ses observations à des savants qui la prenaient pour un Élève de l'École polytechnique. Un prix académique, remporté par elle dans une question horriblement abstruse, l'obligea à dire qui elle était. En vraie mathématicienne, elle n'ambitionnait d'autre titre que celui de Mlle X..."
} 
exception, she had specific opportunities to meet and discuss with several scholars, even if some of them did not consider her as a mathematical equal as she wished. Otherwise, number theory seemed then to be a domain where being excluded from institutions like the École polytechnique was less limiting than for other kinds of mathematics: not taught in educational institutions, number theory was a mathematical domain where self-taught individuals could more easily stand out; in the early nineteenth century, analytical methods were far from being systematically used in number theory, so Germain did not have the same difficulties as with her study of the theory of elasticity. Number theory also appeared as a marginal domain in France and was not a field as competitive as analysis, for example. Germain was definitely one of the first mathematicians to master Gauss' $D A$ and to propose some generalisations and new applications of Gauss' results and methods. She was then able to exchange technical communication on number theory with Gauss, Legendre, Libri and others and could be a bridge between some of them (Gauss and Legendre at least). Germain was aware of most of the recent publications in number theory. She was connected to most of the contemporary mathematicians studying number theory who valued her arithmetical contribution. In connection with most of the mathematicians studying number theory at her time, Germain was valued as a number-theorist among them. The fact that her work was not published extensively can be understood by the limited editorial space, especially for authors who did not belong to institutions such as the Académie des sciences and the École polytechnique, especially for number theory. Germain was thus able to evolve in limited but existing alternative spaces, modeled by her gender but also by personal, social and mathematical factors. This indicates the complexity of women's possibilities in science. ${ }^{90}$

As we saw, the reception of Germain's achievements in number theory depended partially on an editorial project of Gauss's collected papers from the 1860s and a period during which several mathematicians promoted number theory in the context of teaching and science diffusion. At the same time, her philosophical work was reedited and printed with a precise biography of her by Stupuy. During her life, Germain deployed strategies to hide her sex and especially to avoid being considered as a "learned woman". Nevertheless, after her death, and especially under the Third Republic, her name and biography were used to feed the debates on women in mathematics and more generally on the woman question. This recourse to women recognised for their intellectual, and especially scientific successes was indeed frequent, in the daily press and in general and specialised periodicals. References to Germain were thus mobilised for the question of education for women, their social and economic rights, and to defend or attack feminist doctrines. I could also have taken the later example of the discussions on women's suffrage: for example, after having published an article on "The Vote of Women" in La Nouvelle revue in 1922 (Martin, 1922), Senator Louis Martin listed Germain among many accomplished women in defense of his proposed law "to give women the right to vote and eligibility" to the Senate in 1923. The range of types of arguments to discuss these questions expanded during the nineteenth century with the creation and development of natural and social sciences, such as anthropology, sociology, psychology, physiology and statistics.

Beyond the evocations of Germain in lists of names, several characteristics of her personality and her works were also employed to make a point. Her perseverance in the study of mathematics despite the constraints imposed by her family and by the post-revolutionary French society was in turn presented in youth literature as an example to be followed or, on the contrary, as a proof of her lack of genius. Some authors noted Germain's independence from learned men to describe her as a fullfledged mathematician; others, on the contrary, used her epistolary exchanges with Gauss as a proof of her lack of originality, or her tendency to imitation. Similarly, the fact that she was unable to access educational institutions was seen as proof of the need for secondary or even higher education for women (she would have obtained much more original results and educated women could participate in the progress of knowledge) or, on the contrary, as an indication of its uselessness (a truly capable woman in mathematics did not need institutionalised higher education). Generally, apart from the mathematical journals, the substance of Germain's mathematical research was not discussed. It is the moral virtues of the woman mathematician that was debated and their (in)adequacy within French

\footnotetext{
${ }^{90}$ On this issue for mathematics in another period of time, see in particular (Goldstein, 2003).
} 
society. Here we find a situation that is to a certain extent analogous to that of texts celebrating women in early modern France (Goldstein, 2003), for example: Germain's virtues and moral behavior were used as a model or counter-example for other women. She could nevertheless also be mobilised to prove (to men) the interest for society of a better situation for women.

Germain's figure was used extensively to feed discussions concerning women mathematicians or women scientists. Were women capable of mathematics? According to the authors, the answer was often a categorical one: the feminine qualities - patience, assimilation, intuition - were not compatible with the practice of mathematics, which required masculine qualities like creativity, and capacities of abstraction and generalisation. At the end of the nineteenth century, following the first surveys on secondary and higher education for women, this radical position was sometimes softened: women showed certain skills for mathematics, in their learning or even in the first phase of creativity, without showing the rigorous and abstract spirit necessary. In this case, what could explain the case of Germain and other women mathematicians? Either they were considered as second-class mathematicians, who had not actually invented mathematics, or they were described as virile, abnormal or even degenerate. Moreover, Germain's celibacy was sometimes used to show the danger of women practicing mathematics and science: it removed them from their natural roles as wives and mothers and made them unhappy.

Defenders of women's rights and proponents of the intellectual equality of the sexes, on the contrary, often used Germain and other women mathematicians to show that, despite all the limits that women faced, some were still capable of science: the famous intellectual inferiority of women was thus socially constructed. As we have seen, the positions of these feminists on the usefulness of education for women were very diverse: for many of them, the fundamental role of women remained embedded in the family. "Equality in difference" remained the order of the day and Germain was one of the recurring examples to illustrate it, in one way or another.

The examples given above show how women mathematicians, like Germain, ,could be used as historical paradigms or counterexamples to inform debates on education and more generally on the place of women in society. To follow these various receptions of Germain thus appears to be fruitful for analysing the question of women in mathematics and society under the Third Republic in France and the ways in which it was treated according to the various factors considered.

\section{ACKNOWLEDGEMENT}

I warmly thank Deborah Kent for improving the English of this paper.

\section{Références}

Alexanderson Gerald L. (2012), "About the Cover: Sophie Germain and a Problem in Number Theory”, Bulletin of the American Mathematical Society, vol. 49, no. 2, pp. 327-331.

Alfonsi Liliane (2008), "Étienne Bézout : analyse algébrique au siècle des Lumières", Revne d’histoire des mathématiques, vol. 14, no. 2, pp. 211-287.

Angot Emma (1909), "Un peu de féminisme”, Le Correspondant, vol. 81, pp. 951-971.

BARIDON Laurent (2003), "Du portrait comme une science : phrénologie et arts visuels en France au XIX ${ }^{\mathrm{e}}$ siècle”, in Christophe Bouton, Valéry LauRAnd, and Layla RaïD (eds.), La Physiognonomie. Problèmes philosophiques d'une psendo-science, Paris, Éditions Kimé, pp. 143-170.

- (2010), "Viollet-Le-Duc, Eugène-Emmanuel", in Philippe SÉnÉchal and Claire Barbillon (eds.), Dictionnaire critique des historiens de l'art actifs en France de la Révolution à la Première Guerre mondiale, Paris, Institut national d'histoire de l'art (édition numérique), https://www.inha.fr/ $\mathrm{fr} /$ ressources/publications/publications-numeriques/dictionnaire-critique-des-historiens-de-1art/viollet-le-duc-eugene-emmanuel.html. 
Barlow Peter (1811), An Elementary Investigation of the Theory of Numbers: with its Application to the Indeterminate and Diophantine Analysis, the Analytical and Geometrical Division of the Circle, and Several Other Curious Algebraical and Arithmetical Problems, London, Johnson.

Barrau Théodore-Henri (1860), "Récits historiques. Sophie Germain", La Semaine des enfants, vol. 4, no. 173 , pp. 121-122.

- (1872), Livre de morale pratique ou choix de préceptes et de beaux exemples destiné à la lecture courante dans les écoles et dans les familles, Paris, Hachette.

BENTzON Thérèse (1902), "Enquête sur le féminisme", Le Carnet, vol. 11, pp. 433-438.

Bologne Jean Claude (2004), Histoire du célibat et des célibataires, Paris, Fayard.

BOUCARD Jenny (2011), Un "rapprochement curieux de l'algèbre et de la théorie des nombres" : études sur l'utilisation des congruences en France de 1801 à 1850, PhD thesis, Université Pierre et Marie Curie.

- (2015), "Résidus et congruences de 1750 à 1850 : une diversité de pratiques entre algèbre et théorie des nombres", in Christian Gilain and Alexandre Guilbaud (eds.), Les Sciences mathématiques 1750-1850 : continuités et ruptures, Paris, CNRS Éditions, pp. 509-540.

Boucard Jenny and Verdier Norbert (2015), "Circulations mathématiques et congruences dans les périodiques de la première moitié du XIX ${ }^{e}$ siècle”, Philosophia Scientice, vol. 19, no. 2, pp. 57-77.

Boyé Anne (2017), "Sophie Germain, une mathématicienne face aux préjugés de son temps”, Bulletin de l'APMEP, vol. 523, pp. 231-243.

BOYER Jacques (1898), "Les Femmes dans la science”, La Revne des revnes, vol. 26, pp. 600-615.

BRuno G. (1869), Francinet. Principes généraux de la morale, l'industrie, le commerce et l'agriculture, Paris, Belin. Edition used: 1882.

BRUYÈres Jean Hippolyte (1847), La Phrénologie. Le geste et la physionomie démontrés par 120 portraits, sujets et compositions gravés sur acier, Paris, Aubert.

BucCIARelli Louis L. (1980), Sophie Germain: An Essay in the History of the Theory of Elasticity, Boston, Reidel.

CÉre Émile (1896), “Les Femmes de science”, Le Petit journal, vol. September 22, p. 1.

Champagnac Jean-Baptiste-Joseph (1837), Le Gymnase moral des jeunes personnes ou nouvelles anecdotiques relatives à des femmes célèbres de notre siècle, Paris, Lehuby. Edition used: 1856, Paris, Ducrocq.

Chappey Jean-Luc (2004), "Enjeux sociaux et politiques de la 'vulgarisation scientifique' en révolution (1780-1810)", Annales historique de la Révolution française, vol. 338, pp. 11-51.

CORRY Leo (2010), “On the History of Fermat's Last Theorem: Fresh Views on an Old Tale”, Math Semesterber, vol. 57, pp. 123-138.

CuBí I SOlER Mariano (1858), Leçons de phrénologie scientifique et pratique, Paris, Baillière.

D’Abbadie d’Arrast Marie (1897-1898), “Les Femmes dans la science”, La Femme, vol. 19, n' 23 (December 15, 1897), p. 181-183; vol. 20, no 1 (January 1, 1898), p. 3-5; vol. 20 , no 2 (January 15, 1898), p. 10-11; vol. 20, no 3 (February 1, 1898), p. 18; vol. 20, no 4 (February 15, 1898), p. 27-31; vol. 20, nº 5 (March 1, 1898), p. 33-37.

Dahan Dalmedico Amy (1987), "Mécanique et théorie des surfaces : les travaux de Sophie Germain", Historia Mathematica, vol. 14, pp. 347-365.

Del Centina Andrea (2005), "Letters of Sophie Germain Preserved in Florence”, Archive for History of Exact Sciences, vol. 32, pp. 60-75.

- (2008), "Unpublished Manuscripts of Sophie Germain and a Reevaluation of her Work on Fermat's Last Theorem", Archive for History of Exact Sciences, vol. 62, pp. 349-392.

Del Centina Andrea and Fiocca Alessandra (2012), "The Correspondence between Sophie Germain and Carl Friedrich Gauss", Archive for History of Exact Sciences, vol. 66, pp. 585-700.

Delacroix M. (1837-1838), Dictionnaire historique d'éducation, ou choix d'exemples et de faits puisés dans l'histoire ancienne et moderne, propres à former et à enrichir toutes les facultés du coeur et de l'esprit, d'après M. l'abée Filassier, 2 vols., Paris, Angé et Cherest. Edition used : 1847, Paris, Librairie des écoles. 
Dickson Leonard Eugene (1919-1923), History of the Theory of Numbers, 3 vols., Washington, Carnegie Institue of Washington.

D’Ocagne Maurice (1909), “Les Femmes dans la science”, Revue des questions scientifiques, vol. 15, pp. 64-91.

- (1925), Quelques figures de mathématiciennes, Paris, Institut de France.

Edwards Harold M. (1977), Fermat's Last Theorem. A Genetic Introduction to Algebraic Number Theory, New York, Springer-Verlag.

Fage Émile (1894), "Chronique des livres et des revues. 1.- Les Femmes dans la science [... ], par A. Rebière”, Bulletin de la Société des lettres, sciences et arts, vol. 16, pp. 245-255.

FAYOlLE Caroline (2012), "L'éducation est-elle un instrument de l'égalité ? Les débats sur l'éducation des femmes à la période révolutionnaire et post-révolutionnaire", in Éliane VIENNOT (ed.), Revisiter la 'querelle des fermmes'. Discours sur l'égalité/inégalité des sexes, de 1750 aux lendemains de la Révolution, Saint-Étienne, Publications de l'Université de Saint-étienne, pp. 97-107.

Fenster Della (2007), "Gauss Goes West: The Reception of the Disquisitiones Arithmeticae in the USA", in Catherine Goldstein, Norbert Schappacher, and Joachim Schwermer (eds.), The Shaping of Arithmetic after C. F. Gauss's Disquisitiones Arithmeticae, Berlin, Springer, pp. 463-479.

FouilléE Alfred (1893), "La Psychologie des sexes et ses fondements physiologiques”, Revue des deux mondes, vol. 119, pp. 397-429.

- (1895), Tempérament et caractère selon les individus, les sexes et les races, Paris, Félix Alcan.

Françoise Mayeur (1979), L'Éducation des filles en France au XIXe siècle, Paris, Hachette.

GARDey Delphine (2000), "Histoire de pionnières", Travail, genre et sociétés, vol. 2, pp. 29-34.

- (2005), "La Part de l'ombre ou celle des lumières ? Les sciences et la recherche au risque du genre", Travail, genre et sociétés, vol. 14, pp. 29-47.

Gauss Carl Friedrich (1799), Demonstratio nova theorematis omnem functionem algebraicam rationalem integram unius variabilis in factores reales primi vel secundi gradus resolvi posse, Helmstedt, C. G. Fleckeisen.

- (1801), Disquisitiones Arithmeticae, Leipzig, Fleischer.

- (1808), "Theorematis arithmetici demonstratio nova", Commentationes Societatis Regiae Scientiarum Gottingensis recentiores (Commentationes mathematicae), vol. 16, pp. 69-74.

- (1811), "Summatio quarundam serierum singularium", Commentationes societatis regiae scientiarum Gottingensis recentiores, vol. 1.

- (1818), "Theorematis fundamentalis in doctrina de residuis quadraticis demonstrationes et ampliationes novae", Commentationes societatis regiae scientiarum Gottingensis recentiores, vol. 4, pp. 3-20.

- (1828), "Theoria residuorum biquadraticorum, Commentatio prima”, Commentationes societatis regiae scientiarum Gottingensis recentiores, vol. 6, pp. 27-56.

GoldsteIn Catherine (2003), "Weder Öffentlich Noch Privat: Mathematik im Frankreich des frühen 17. Jahrhunderts", in Theresa Wовве (ed.), Zwischen Vorderbühne Hinterbühne. Beiträge zum Wandel der Geschlechterbeziehungen in der Wissenschaft vom 17. Jahrbundert bis zur Gegenwart, Bielefeld, Transcript, pp. 41-72.

- (2009), "Gabriel Lamé et la théorie des nombres: 'une passion maheureuse’ ?”, Bulletin de la SABIX, vol. 44, pp. 131-139.

GoldsTEIN Catherine and SCHAPPACHER Norbert (2007), "A Book in Search of a Discipline (1801 1860)", in Catherine Goldstein, Norbert Schappacher, and Joachim Schwermer (eds.), The Shaping of Arithmetic after C. F. Gauss's Disquisitiones Arithmeticae, Berlin, Springer, pp. 3-65.

Govoni Paola (2000), "Biography: a Critical Tool to Bridge the History of Science and the History of Women in Science", Nuncius, vol. 15, no. 1, pp. 399-409.

Haechler Jean (2017), Les Insoumises : 18 portraits de femmes exceptionnelles, Paris, Nouveau Monde éditions.

Hulin Nicole (2008), Les Femmes, l'Enseignement et les Sciences. Un long cheminement (XIXe-XXe siècle), Paris, L'Harmattan. 
JoLy Nicolas Joseph (1885), "Dans l'espèce humaine à égalité d'instruction les intelligences sont égales chez les deux sexes. Preuves nombreuses à l'appui de cette assertion”, Mémoires de l'Académie des sciences, inscriptions et belles-lettres de Toulouse, 8th ser., vol. 7, pp. 131-158.

Јотеуко Jòzefa (1904), “À propos des femmes mathématiciennes”, Revne scientifique, vol. 21, pp. 12-15. Kalifa Dominique, RÉgnier Philippe, Therenty Marie-Ėve, and Vaillant Alain (eds.) (2011), La Civilisation du journal: histoire culturelle et littéraire de la presse française an XIX siècle, Paris, Nouveau Monde éditions.

Kaluszynski Martine (1989), “Les Congrès internationaux d'anthropologie criminelle (1885-1914)”, Mil neuf cent, vol. 7, no. 1, pp. 59-70.

KNibiehler Yvonne (1976), “Le Discours sur la femme : constantes et ruptures”, Romantisme, vol. 6, no. 13 , pp. $41-55$.

Lacassagne Alexandre (1906), Précis de médecine légale, Paris, Masson.

Lacroix Sylvestre-François (1804), Complément des élémens d'algèbre, 3rd ed., Paris, Courcier.

Laqueur Thomas Walter (1992), La Fabrique du sexe : essai sur le corps et le genre en Occident, Paris, Gallimard.

Laubenbacher Reinhard and Pengelley David (1999), Mathematical Expeditions: Chronicles by the Explorers, SPRINGER (ed.), New York.

- (2010), “Voici ce que j’ai trouvé' : Sophie Germain’s Grand Plan to Prove Fermat's Last Theorem”, Historia Mathematica, vol. 37, pp. 641-692.

LEGENDRE Adrien-Marie (1798), Essai sur la théorie des nombres, Paris, Duprat.

- (1827), "echerches sur quelques objets d'analyse indéterminée et particulièrement sur le théorème de Fermat", Mémoires de l'Académie royale des sciences de l'Institut de France, vol. 6, pp. 1-60.

Legouvé Ernest Wilfred (1849), Histoire morale des femmes, Paris, Gustave Sandré.

Lemay Edna Hinie (1991), Dictionnaire des Constituants (1789-1791), 2 vols., Paris, Universitas.

LiARD Louis (1879), “Analyses. Sophie Germain. CEuvres philosophiques...”, Revue philosophique de la France et de l'étranger, vol. 8, pp. 426-431.

Lombroso Cesare and Ferrero Guglielmo (1893), La donna delinquente, la prostituta e la donna normale, Torino, Roux. French Translation by Louise Meille, La Femme criminelle et la prostituée, Paris, Félix Alcan, 1896.

LORIa Gino (1903), "Les Femmes mathématiciennes", La Revue scientifique, vol. 20, pp. 385-392.

- (1904), "Encore les Femmes mathématiciennes", La Revue scientifique, vol. 21, pp. 338-340.

Lourbet Jacques (1896), La Femme devant la science contemporaine, Paris, Félix Alcan.

MacKinnon Nick (1990), "Sophie Germain or Was Gauss a Feminist?", The Mathematical Gazette, vol. 74, no. 470, pp. 346-351.

Mansion Paul (1880), "Bibliographie", Nouvelle correspondance mathématique, vol. 6, pp. 407-408.

Marion Henri (1900), Psychologie de la femme, Paris, Armand Colin.

Martin Louis (1922), "Le Vote des femmes", La nouvelle revue, vol. 44, pp. 137-148.

Möвıus Paul Julius (1900), Ueber die Anlage zur Mathematik, Leipzig, Johann Ambrosius Barth.

Mosconi Nicole (2012), "Henri Marion et 'l'égalité dans la différence”, Le Télémaque, vol. 41, no. 1, pp. 133-150.

Musielak Dora E. (2015), Prime Mystery: The Life and Mathematics of Sophie Germain, Bloomington, Authorhouse.

OfFen Karen (1986), "Ernest Legouvé and the Doctrine of 'Equality in Difference' for Women: A Case Study of Male Feminism in Nineteenth-Century French Thought", The Journal of Modern History, vol. 58, no. 2, pp. 452-484.

- (2012), European Feminisms 1700-1950. A Political History, Stanford, Stanford University Press. French translation by Geneviève Knibiehler, Les Féminismes en Europe, 1700-1950. Rennes, Presses universitaires de Rennes, 2012.

- (2018), Debating the Woman Question in the French Third Republic, 1870-1920, Cambridge (GB), Cambridge University Press. 
PARShall Karen Hunger (2015), "Training Women in Mathematical Research: The First Fifty Years of Bryn Mawr College (1885-1935)”, The Mathematical Intelligencer, vol. 37, no. 2, pp. 71-83.

PARville Henri de (1893), "Revue des sciences", Journal des débats politiques et littéraires, vol. December 20 , pp. $1-2$.

Peiffer Jeanne (1991), "L'Engouement des femmes pour les sciences au XVIII e siècle", in Danielle HaASEDubosc and Elianne Viennot (eds.), Femmes et Pouvoirs sous l'Ancien Régime, Paris, Éditions Rivages, pp. 196-222.

Peyre Évelyne and Wiels Joëlle (1995), “De la 'nature des femmes' et de son incompatibilité avec l'exercice du pouvoir : le poids des discours scientifiques depuis le XviII siècle", in Éliane VIENNOT (ed.), La Démocratie à la française' ou les femmes indésirables, Paris, Presses de l'université de Paris VII, pp. 127-157.

PoInsot Louis (1820), "Mémoire sur l'application de l'algèbre à la théorie des nombres", Journal de l'École polytechnique, vol. 11, pp. 342-410.

Rebière Alphonse (1894), Les Femmes dans la science, 2nd ed., Paris, Librairie Nony et Cie.

- (1897), Les Femmes dans la science, Paris, Librairie Nony et Cie.

Renate Tobies, Gispert Hélène (trans., comm.), Peiffer Jeanne (trans., and comm.) (2001), "Femmes et Mathématiques dans le monde occidental, un panorama historiographique", Gazette des mathématiciens, vol. 90 , pp. 26-35.

Rengade J. (1881), La Vie normale et la Santé. Traité complet de la structure du corps humain, Paris, Librairie illustrée.

Roussel Pierre (1775), Système physique et moral de la fermme ou Tableau philosophique de la constitution, de l'état organique, du tempérament, des moeurs, E des fonctions propres au sexe, Paris, Vincent.

Rouzade Léonie (1887), “Les Femmes devant la démocratie”, La Revue socialiste, vol. 5, pp. 519-534.

Rowold Katharina (2001), "The Many Lives and Deaths of Sofia Kovalevskaia: Approaches to Women's Role in Scholarship and Culture in Germany at the Turn of the Twentieth Century”, Women's History Reviere, vol. 10, no. 4, pp. 603-627.

SAgnol Joannès (1889), "L'Égalité des sexes”, La Revne socialiste. vol., p. 685-697; vol. 10, p. 82-98.

SECOND L.-A. (1879), "Enseignement de la biologie", La Nowvelle revue, vol. 1, pp. 263-282.

Sмiтн Henry J. S. (1859-1865), "Report on the Theory of Numbers", Report of the British Association for the Advancement of Science, Oxford, Oxford Clarendon Press. 1859, p. 228-267; 1860, p. 120-169; 1861, p. 292-340; 1862, p. 503-526; 1863, p. 768-786; 1865, p. 322-337. Repr. in The Collected Mathematical Papers, ed. J.W.L. Glaisher, vol. 1, Oxford, Clarendon Press, 1894, p. 38-364.

StupuY Hyppolyte (1879), Euvres philosophiques de Sophie Germain, Paris, Ritti.

- (1896), "Préface à la nouvelle édition", Cuvres philosophiques de Sophie Germain, 2nd ed., Paris, Firmin Didot.

Szramkiewicz Romuald (1974), Szramkiewicz, Romuald, Genève, Droz.

Terquem Olry (1860), "Biographie. Sophie Germain", Nouvelles annales de mathématiques (Supplément: Bulletin de bibliographie, d'histoire et de biographie mathématiques), I, vol. 19, pp. 9-13.

VACHEROT Étienne (1869), La Religion, Paris, Chamerot \& Lauwereyns.

Waterhouse William C. (1994), “A Counterexample for Germain”, The American Mathematical Monthly, vol. 101, pp. 140-150.

WeInINGer Otto (1903), Geschlecht und Charakter. Eine prinzipielle Untersuchung, Wien \& Leipzig, Wilhelm Braumüller. English translation by Löb Ladislaus: Sex E Character: an Investigation of Fundamental Principles, Daniel Steuer and Laura Marcus (eds). Bloomington, Indiana University Press, 2005.

Wils Kaat (2005), "Le Génie s'abritant sous un crâne féminin ? La carrière belge de la physiologiste et pédologue Iosefa Ioteyko", in Jacqueline Carroy, Nicole Edelman, Annick Ohayon, and Nathalie Richard (eds.), Les Femmes dans les sciences de l'homme (XIX ${ }^{e}-X X^{e}$ siècles), Paris, Seli Arslan, pp. 49-67.

WitT Henriette de (1888), Les Femmes dans l'histoire, Paris, Hachette. 